\title{
Nulová izochiona v rámci geomorfologických oblastí Česka: její určení ze snímků MODIS a její dynamika
}

\section{LIBOR DUCHÁČEK, ONDŘEJ LEDVINKA}

Klíčová slova: dálkový průzkum Země (DPZ) - geografické informační systémy (GIS) - sněhová pokrývka zásoby vody ve sněhu - hydrologie ČHMÚ - geomorfologie Česka

\section{SOUHRN}

Od prosince 2012 je pro potřeby operativní hydrologie v Českém hydrometeorologickém ústavu (ČHMÚ) pravidelně pro každou zimní sezonu určována poloha nulové izochiony (sněhové čáry). Dưvodem je odhad zásob vody ve sněhové pokrývce, s nimiž čeští hydrologové musejí nutně pracovat, pokud chtějí, aby jejich předpovědní modely poskytovaly relevantní výsledky. Pro lepší představu o aktuální prostorové distribuci sněhové pokrývky v Česku je informace o nulové izochioně odvozována ze snímků MODIS pořizených družicí Terra. Získaná časová řada reprezentuje již poměrně dlouhé období (nyní až do května 2021), a tak se nabídla možnost analýzy prostorové a časové dynamiky nulové izochiony v Česku. V této studii byla informace o izochioně rozdělena do 27 geomorfologických oblastí, přičemž zimní sezona byla začleněna také do období akumulace a tání sněhu. Snahou bylo zjistit, jaké jsou rozdíly mezi oblastmi a jednotlivými obdobími a jaké jsou vazby dynamiky nulové izochiony na vybrané faktory odvozené z dalších geografických dat, jako je digitální model reliéfu apod. Data o izochioně byla z nejrůznějších důvodů neúplná a nevyhovovala nasazení modelů, které vyžadují pravidelné rozestupy v čase. Proto bylo přistoupeno k odhadu chybějicích denních hodnot tak, aby byly pravidelně pokryty zimní sezony vždy od listopadu do května. To bylo provedeno vhodnou modifikací EM algoritmu, jež zohledňuje jak strukturu časové řady, tak prostorové vazby. Následně byla aplikována korelační a regresní analýza, při níž bylo hlavním cílem zjistit, do jaké míry má vliv př́slušnost ke geomorfologické oblasti (s jejími vybranými atributy) a zda dochází k signifikantním meziročním změnám.

\section{ÚVOD}

Nulová izochiona je již více než deset let praktickým pomocníkem při výpočtech zásob vody ve sněhu v rámci pravidelných hydroprognózních analýz pod hlavičkou ČHMÚ. Hlavním přinosem určování této izochiony je vymezení prostoru, kde Ize předpokládat výskyt sněhové pokrývky a kde naopak sněhová pokrývka bude chybět, respektive kde Ize počítat s vodní hodnotou sněhu a kde nikoli. Definování takové hranice $v$ rámci homogenních regionů Česka umožňuje lépe interpolovat hodnoty výšky sněhové pokrývky zaznamenané ve staniční síti ČHMÚ. Bližší popis hydroprognózních analýz, včetně aplikace nulové izochiony při výpočtech, nabízí [1, 2]. Obsah tohoto článku navazuje na práci [3], kde byly shrnuty základní postupy extrakce nulové izochiony pomocí družicových snímků a informace o jejím rozložení v rámci geomorfologických oblastí Česka. Právě hledání korelací a dalších vazeb, které se dají ze sledované řady vypozorovat, jsou nosným tématem následujícího textu. Jednou ze stěžejních oblastí studia je kvantifikace míry závislosti variability prưměrné nadmořské výšky nulové izochiony na terénních charakteristikách geomorfologických oblastí. Analyzována je jak dlouhodobá nadmořská výška nulové izochiony za celé zimní období vymezené měsíci listopadem až květnem (pro devět let 2013-2021), tak i v částech zimní sezony typických pro akumulaci sněhu, pro jeho tání a ve zbylé části této sezony (pro čtyři roky 2018-2021). Snahou bylo vysledovat míru pưsobení faktorů souvisejících s konfigurací terénu v jednotlivých obdobích zimní sezony. Jelikož délka nasbírané časové řady je již poměrně dostačující (ve smyslu nečleněné zimní sezony), neméně důležitým úkolem bylo zjistit, jak se mění nadmořská výška nulové izochiony s časem, tj. v jednotlivých letech, a zda Ize vypozorovat významný trend u některých geomorfologických oblastí. Při extrakci nadmořské výšky nulové izochiony a respektování její definice dle [4] bylo z důvodu nutné konzistence postupováno obdobně jako v [3]. Řešení nových úkolů bylo provedeno s využitím nejrůznějších statistických technik, přičemž kromě deskriptivní statistiky a metod pro doplňování chybějících hodnot hrála ústřední roli regresní analýza a výběr významných vysvětlujících proměnných.

\section{DATA A METODIKA}

\section{Družicová data}

Podstatná část dat analyzovaných v rámci tohoto projektu pochází z portálu Národního střediska sněhu a ledu (National Snow and Ice Data Center, dále NSIDC), které podporuje výzkum kryosféry, tedy sněhu, ledu, ledovců a zmrzlé půdy, ale i klimatických interakcí, jež v kryosféře probíhají. NSIDC spravuje a distribuuje vědecká data, vytvárí nástroje pro prístup k datům, podporuje uživatele dat, provádí vědecký výzkum a vzdělává veřejnost o kryosféře. Jako platforma dat pocházejících z Národního úřadu pro letectví a vesmír (National Aeronautics and Space Administration, NASA) je zároveň certifikována coby tzv. CoreTrustSeal s osvědčením Pravidelný člen Světového datového systému, mezioborového orgánu Mezinárodní vědecké rady (International Science Council, ISC; dřive ICSU). Portál distribuuje data bezplatně celé vědecké komunitě již od roku 1976 v rozmanitých formátech známých v oblasti DPZ a ve velikostech od malých textových souborů po terabyty dat. Bližši informace o produktech, nástrojích i publikovaných výstupech Ize dohledat na [5]. 
Konkrétní datová sada využitá pro účely analýzy nulové izochiony je označena jako MODIS/Terra Snow Cover 5-Min L2 Swath 500m, Version 61 a je včetně metadat dostupná z [6]. Název sady obsahuje základní popisné údaje o snímaných datech. Snímky jsou sbírány pomocí senzoru MODIS (Moderate Resolution Imaging Spectroradiometer), který je instalován na družici Terra. Terra je nadnárodní vědecký výzkumný satelit NASA na sluneční synchronní oběžné dráze kolem Země, jenž provádí simultánní měření zemské atmosféry, pưdy a vody, aby přispěl k pochopení, jak se Země mění, a identifikoval důsledky pro život na Zemi [7]. Umístění senzoru MODIS na družici Terra ukazuje obr. 1.

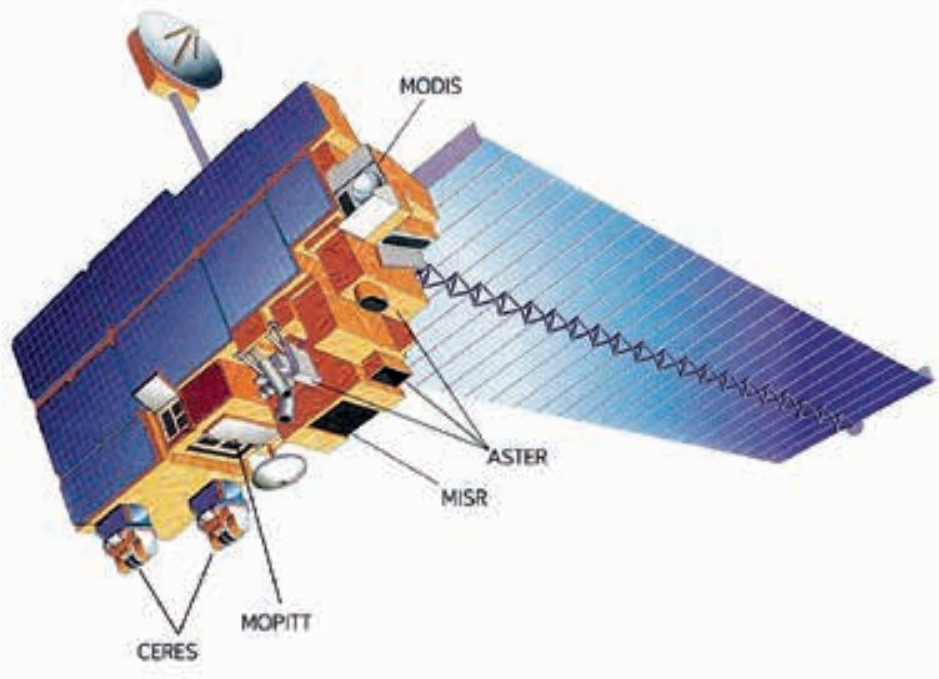

Obr. 1. Družice Terra, vypuštěná 18. prosince 1999 (výška oběžné dráhy: 713 km; rychlost na oběžné dráze: $7503 \mathrm{~km} \cdot \mathrm{s}^{-1}$; maximální rychlost: $27010 \mathrm{~km} \cdot \mathrm{h}^{-1}$ ) a poloha senzoru MODIS (zdroj: [8])

Fig. 1. Terra satellite, launched $18^{\text {th }}$ December 1999 (orbit height: $713 \mathrm{~km}$; orbital velocity: $7503 \mathrm{~km} \cdot \mathrm{s}^{-1}$; maximum velocity: $27010 \mathrm{~km} \cdot \mathrm{h}^{-1}$ ) and the position of the MODIS sensor (source: [8])

Snímky označené identifikátorem MOD10_L2 poskytují informaci o sněhové pokrývce $v$ denním kroku. Detekce probíhá pomocí normalizovaného diferenčního sněhového indexu (Normalized Difference Snow Index, NDSI). Dalším produktem je série korekčních snímků určených ke zmírnění chyb a označení detekce nejisté sněhové pokrývky. Zasněžená krajina má obvykle velmi vysokou odrazivost ve viditelných pásmech a velmi nízkou odrazivost pro krátkovinná infračervená pásma. NDSI odhaluje velikost tohoto rozdílu. Každá datová granule obsahuje 5 minut dat ze svazku pozorovaných v rozlišení 500 m. Sběr dat byl zahájen 24. února 2000 a v současnosti probíhá revize dat pro aktuální verzi 61, která by měla být dokončena na jaře 2022.

\section{Stažení družicových dat a jejich zpracování v prostředí GIS}

Praktická stránka zpracování těchto dat v ČHMú spočívá v přednastavení parametrů zájmové oblasti na obdélník překrývající území Česka. Pokud je pořízený snímek $v$ průniku s tímto obdélníkem, jsou v nejbližším termínu pracovníci ČHMÚ e-mailem informováni o jeho dostupnosti s odkazem ke stažení daného datového souboru. Termín zaslání závisí na komplexnosti snímku. V případě, že se snímek vyznačuje velkým množstvím tříd, může docházet ke zpoždění. Nejčastěji však bývají notifikace zasílány do 12 hodin od pořízení.

Data jsou poskytována ve formátu HDF-EOS2 a jsou ukládána jako 8bitová celá čísla bez znaménka. Datový formát HDF (Hierarchical Data Format) umožňuje efektivně ukládat rozsáhlá, a pritom poměrně rozmanitá data a metadata [9].
Tab. 1. Trídy výstupu NDSI Snow Cover

Tab. 1. Classes of the NDSI_Snow_Cover output

NDSI sněhová pokrývka a hodnoty datových vlaječek (uložené jako 8bitové hodnoty bez znamének)

0-100: NDSI sněhová pokrývka

200: chybějící data

201: bez rozhodnutí

211: noc

237: vnitrozemská voda

239: oceán

250: oblačnost

254: nasycený detektor

255: vyplnění

Pro zájmovou oblast zahrnující území Česka je velikost takových souborů přibližně 5-25 MB, což odráží plochu a prostorovou distribuci sněhu $v$ krajině. Každý HDF soubor je složen z několika parametrů, z nichž je pro detekci sněhu zásadní výstup „NDSI_Snow_Cover", který obsahuje příznaky rozdělené do devíti tříd uvedených v tab. 1 .

Pro navazující práci v prostředí GIS je nutné extrahovat jednotlivé třídy nejprve do rastrové podoby a následně do polygonů, z nichž je využita zásadní hranice mezi oblastí se sněhem a bez sněhu. V první fázi extrahování je nutné použít nástroj HEG (HDF-EOS To GeoTIFF Conversion Tool), který je volně dostupný jako podpůrný software z portálu NASA [10]. Umožňuje dostatečně přesnou konverzi z HDF formátu do GeoTIFF formátu tak, aby při projekci UTM a zadání odpovídající zóny (pro Česko 33N, nebo 34N na východě) došlo k plnohodnotnému překryvu s českým digitálním modelem reliéfu (DMR; k němu viz dále). Nejlepším ověřením kvality překryvu jsou lokální odrazy ve tř́dě 237, tedy vnitrozemské vodní plochy, které lícují s hydrografickým podkladem v GIS (např. vodní nádrže Rozkoš nebo Nové Mlýny). Příklad nastavení nástroje HEG znázorňuje obr. 2.

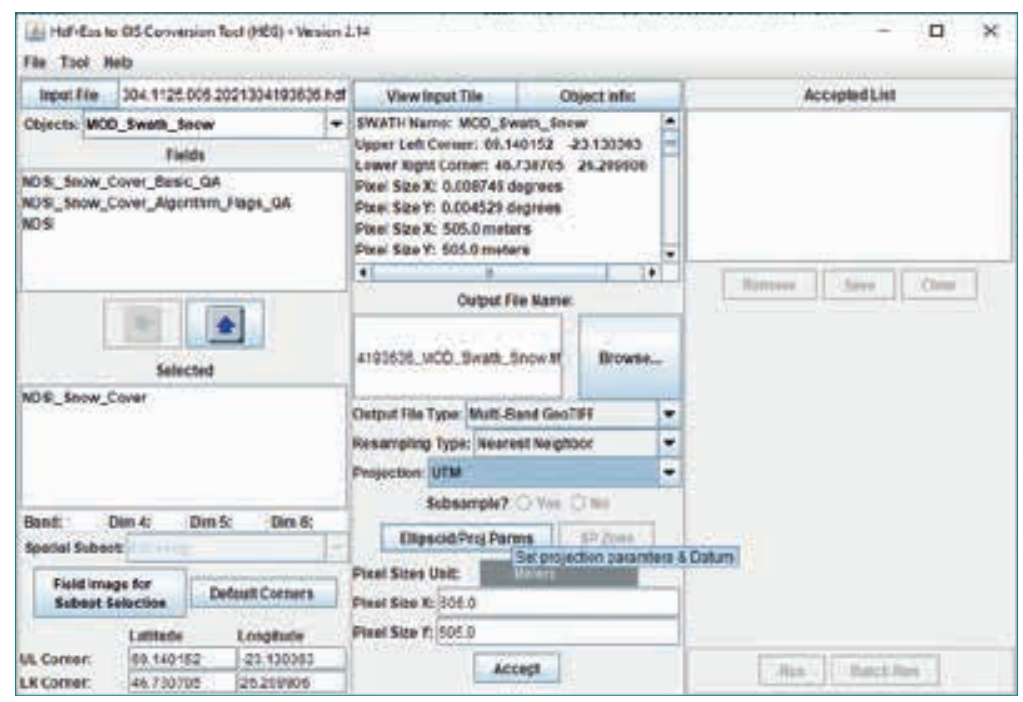

Obr. 2. Nastavení parametrů pro konverzi v nástroji HEG

Fig. 2. Parameter settings for conversion in the HEG tool 
Zpracování snímků v prostředí ArcGIS Desktop Ize rozdělit do několika fází, přičemž použití jednotlivých nástrojů se přizpůsobuje možnostem licence ArcGIS Desktop v rámci ČHMÚ a do budoucna Ize též předpokládat adaptaci na novější verze a produkty:

A. Extrakce zájmových dat ze snímku DPZ. Snímek ve formátu GeoTIFF je importován s parametry nastavenými v nástroji HEG (projekce, rozsah). Nejčastěji je pro oblast Česka pořizen snímek v dopoledních hodinách, jenž obsahuje území přibližně od jižní Skandinávie po oblast Alp. V méně častých prípadech Ize použít i snímky jen s částečným překryvem, což vychází z orbitální dráhy družice, která území Česka může zaznamenat z více přeletů. Snímky, jež mají průnik s přednastavenou obdélníkovou maskou pro Česko, jsou podrobeny ořezu, aby se snižila náročnost dílčích výpočtů. Získaný rastr je nutné nejprve reklasifikovat s ohledem na vymezení oblastí se sněhem a bez sněhu. Pưvodní data do roku 2017 byla koncipována obecněji do tři základních tříd: sníh, bez sněhu a oblačnost. Po roce 2017 je již kvalita odrazu ze sněhové pokrývky rozdělována detailněji do tř́íd o hodnotách 0 až 100 (dle indexu NDSI), kde 0 je zaručená oblast bez sněhu a 100 je nejvyšší možná odrazivost od sněhové pokrývky. Pro účely hydrologie ČHMÚ jsou veškeré hodnoty pro odraz sněhu v rozmezí 1 až 100 považovány jako sníh, aby bylo možné získat co největší balík dat pro vyhodnocení nulové izochiony. Ve výsledku jsou tedy všechny hodnoty 1-100 překlasifikovány do hodnoty 50 a hodnoty 0 jsou brány jako území bez sněhu. Významným prvkem vycházejícím z aktuálních podmínek počasí je třída o hodnotě 201, což je území se sporným vyhodnocením (interní výpočet NDSI), a třída o hodnotě 250, což je oblačnost, která je nejčastějším limitujícím faktorem pro plnohodnotné vyhodnocení. Ostatní trrídy lze považovat za doplňkové a je možné je z dalších operací vynechat. Reklasifikovaný rastr je ještě generalizován nástrojem Boundary Clean, aby byly potlačeny dílčí mikroregiony o velikostech jednotek pixelů, a poté jsou třídy barevně označeny, aby vynikl primární vizuální přehled o datové sadě. Pro další operace je nejprve nutné převést rastrovou vrstvu na polygonovou a tu následně na liniovou pomocí nástroje Feature to Line. Takto vznikne datová sada linií, jež mají specifický gridcode dle původního rastru, který obklopovaly. Konkrétně, na kontaktu dvou polygonů, kde jeden je o hodnotě 0 (bez sněhu) a druhý o hodnotě 50 (sníh), vzniknou dvě linie, jedna s gridcodem 0 a druhá s gridcodem 50 . Hledaným prvkem je následně vrstva, která vznikne průnikem výběrů (nástroj Intersect) těchto dvou linií a obsahuje všechny viditelné hranice mezi oblastmi se sněhem a bez sněhu. Tuto nesouvislou linii ohraničující zaznamenanou sněhovou pokrývku Ize označit za nulovou izochionu. Tato linie již poskytuje jistou prostorovou představu o pozici hranice sněhu v rámci území Česka. Pro bližší údaj o pozici je nutné najít přibližnou hodnotu nadmořské výšky, v niž se tato linie nachází. Jako nejjednodušší metoda byla zvolena extrakce pixelů pomocí masky, kde za masku je považována právě linie izochiony. Takto jsou extrahovány hodnoty nadmořské výšky z rastrového podkladu, kterým je DMR o rozlišení 25 m (viz dále).

B. Prostorová analýza dat. Jako nejvhodnější dělení území Česka byly pro potřeby definice nulové izochiony zvoleny geomorfologické oblasti. Ty nejlépe odrážejí vlastnosti reliéfu, relativní i absolutní členitost (pohoří/nížiny) a rozdělení orientace svahů k jednotlivým světovým stranám (sever/jih, západ/východ), tedy faktory, u nichž je předpokládán zásadní vliv na akumulaci a tání sněhové pokrývky. V rámci Česka je takových zpracovávaných oblastí 27 (blíže viz tab. 2 a obr. 3). Pro každou z těchto oblastí je pomocí nástroje Zonal Statistics as Table vyhodnocen extrahovaný soubor pixelů přináležející dané geomorfologické oblasti a výstupem je statistika obsahující informace o počtu pixelů, jejich minimální a maximální hodnotě, rozsahu hodnot, sumě hodnot a především prưměrné hodnotě, což je položka, se kterou je následně pracováno. Vektorová vrstva geomorfologických oblastí supluje funkci databáze poloh nulové izochiony, jelikož pro každý analyzovaný den je vytvořen sloupec hodnot, kde je každé geomorfologické oblasti přiřazena hodnota průměrné polohy, pokud v daný den byla zaznamenána. Pro propojení statistického výstupu s atributovou tabulkou vrstvy oblastí je použit nástroj Join Field.

C. Vizuální interpretace dat. Vizualizaci hodnot lze provést pomocí labelingu hodnot pro jednotlivé oblasti, prípadně i s podbarveným kartogramem. Situace, kdy je definována průměrná hodnota pro každou nebo alespoň pro většinu geomorfologických oblastí, je během pozorování spíše výjimečná, nebot' se často projevuje faktor oblačnosti a při absenci oblačnosti je sníh bud' omezen jen na horské oblasti, nebo naopak pokrývá celé území Česka. Jakjiž bylo zmíněno výše, hranice sněhu vychází z různé intenzity indexu odrazivosti NDSI a každou z průměrných hodnot je potřeba podrobit kritické analýze (neboli validovat), zda jde o objektivní hodnotu a zda může reprezentovat podmínky v dané oblasti. Při posouzení se vychází nejen z interních dat o sněhové pokrývce pocházejících z pozorovací sítě ČHMÚ (automatické stanice, pozorovatelé, terénní měření), ale napríklad i z výstupů webových kamer nebo historické korelace mezi oblastmi. Do výpočtu zásob vody ve sněhu vstupuje poloha nulové izochiony jako limitní hodnota pro prostorovou interpolaci parametrů sněhové pokrývky, kdy je pro každou z oblastí vygenerována virtuální sit nulových bodů, jež zamezuje interpolaci odhadovat nenulovou (kladnou) výšku sněhové pokrývky nebo vodní hodnotu sněhu pod touto pozicí. Pro tuto analýzu v prostředí GIS se použivá nástroj ClidataGIS, který umožňuje import naměřených dat, jejich detailnějši vizuální kontrolu i nastavení parametrů pro interpolaci. Finálním výstupem je mapa včetně doplňující tabulky zohledňující změny ve výskytu sněhu v předchozích týdnech, jež je vyvěšena na portálu ČHMÚ, a veřejnost se zde může seznámit s předpokládaným objemem vody v dílčich zájmových povodích (vodní nádrže, významné závěrové profily vodních tokü). Aktuálně je takový výstup, vycházející z pondělních změřených hodnot, generován jednou týdně, a to v úterý. Do budoucna bude ovšem díky automatizované síti sněhoměrných stanic v kombinaci se satelitními snímky možné zpracovat podobné analýzy i častěji během týdne.

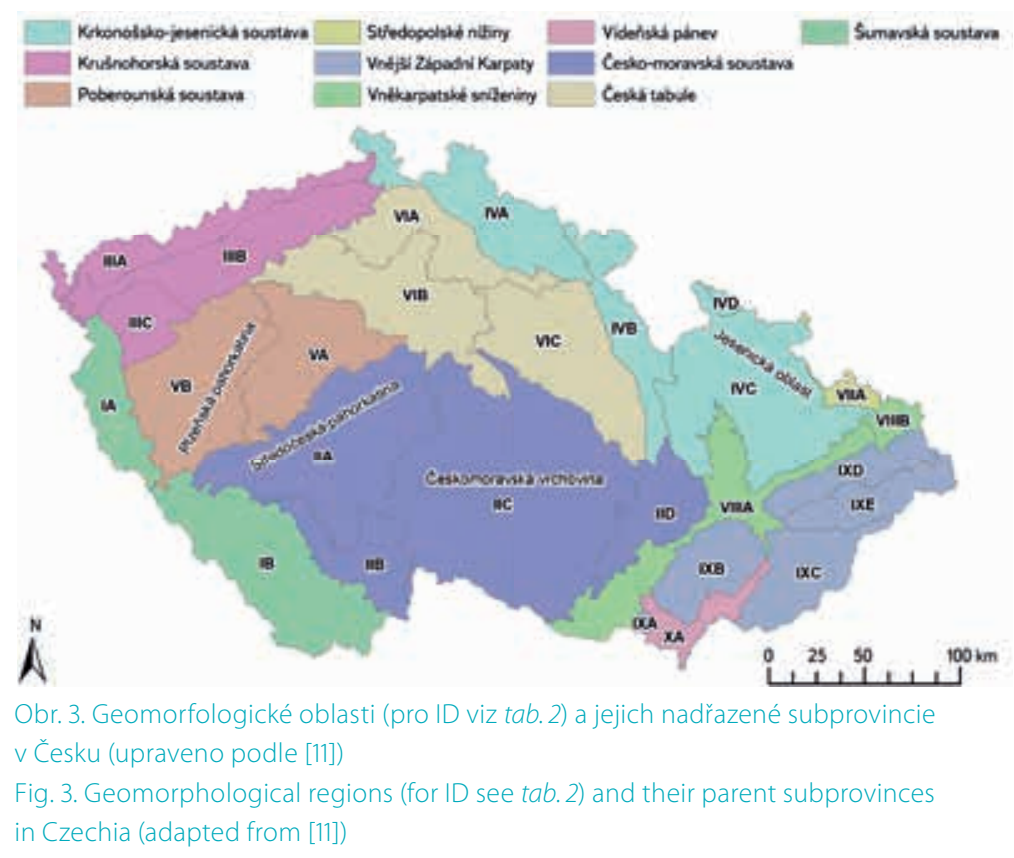

\section{Základní geografické podklady pro získání terénních vysvětlujících proměnných}

Na prostorovou (ale i časovou) variabilitu nadmořské výšky nulové izochiony má vliv konfigurace terénu. Časová variabilita bude jistě více spjata s klimatickými podmínkami územních celků, pro které je studium prováděno. Vzhledem 
Tab. 2. Geomorfologické oblasti, pro kteréjev ČHMú v zimní sezoně určována průměrná nadmořská výška nulové izochiony, a jejich identifikátory (upraveno podle [11]) Tab. 2. Geomorphological regions for which, in the winter season, the CHMI determines the average altitude of the zero isochion, and their identifiers (adapted from [11])

\begin{tabular}{|c|c|c|c|c|}
\hline ID & Oblast/Region & Subprovincie/Subprovince & Provincie/Province & Systém/System \\
\hline $\mid \mathrm{A}$ & Českoleská oblast & Šumavská soustava & Česká vysočina & Hercynský \\
\hline $\mathrm{IB}$ & Šumavská hornatina & Šumavská soustava & Česká vysočina & Hercynský \\
\hline$\| \mathrm{A}$ & Středočeská pahorkatina & Česko-moravská soustava & Česká vysočina & Hercynský \\
\hline$\| \mathrm{B}$ & Jihočeské pánve & Česko-moravská soustava & Česká vysočina & Hercynský \\
\hline IIC & Českomoravská vrchovina & Česko-moravská soustava & Česká vysočina & Hercynský \\
\hline IID & Brněnská vrchovina & Česko-moravská soustava & Česká vysočina & Hercynský \\
\hline IIIA & Krušnohorská hornatina & Krušnohorská soustava & Česká vysočina & Hercynský \\
\hline IIIB & Podkrušnohorská oblast & Krušnohorská soustava & Česká vysočina & Hercynský \\
\hline IIIC & Karlovarská vrchovina & Krušnohorská soustava & Česká vysočina & Hercynský \\
\hline IVA & Krkonošská oblast & Krkonošsko-jesenická soustava & Česká vysočina & Hercynský \\
\hline IVB & Orlická oblast & Krkonošsko-jesenická soustava & Česká vysočina & Hercynský \\
\hline IVC & Jesenická oblast & Krkonošsko-jesenická soustava & Česká vysočina & Hercynský \\
\hline IVD & Krkonošsko-jesenické podhůří & Krkonošsko-jesenická soustava & Česká vysočina & Hercynský \\
\hline IXA & Jihomoravské Karpaty & Vnější Západní Karpaty & Západní Karpaty & Alpsko-himálajský \\
\hline IXB & Středomoravské Karpaty & Vnější Západní Karpaty & Západní Karpaty & Alpsko-himálajský \\
\hline IXC & Slovensko-moravské Karpaty & Vnější Západní Karpaty & Západní Karpaty & Alpsko-himálajský \\
\hline IXD & Západobeskydské podhůří & Vnější Západní Karpaty & Západní Karpaty & Alpsko-himálajský \\
\hline IXE & Západní Beskydy & Vnější Západní Karpaty & Západní Karpaty & Alpsko-himálajský \\
\hline VA & Brdská oblast & Poberounská soustava & Česká vysočina & Hercynský \\
\hline VB & Plzeňská pahorkatina & Poberounská soustava & Česká vysočina & Hercynský \\
\hline VIA & Severočeská tabule & Česká tabule & Česká vysočina & Hercynský \\
\hline VIB & Středočeská tabule & Česká tabule & Česká vysočina & Hercynský \\
\hline VIC & Východočeská tabule & Česká tabule & Česká vysočina & Hercynský \\
\hline VIIA & Slezská nížina & Středopolské nížiny & Středoevropské nížiny & Hercynský \\
\hline VIIIA & Západní vněkarpatské sníženiny & Vněkarpatské sníženiny & Západní Karpaty & Alpsko-himálajský \\
\hline VIIIIB & Severní vněkarpatské sníženiny & Vněkarpatské sníženiny & Západní Karpaty & Alpsko-himálajský \\
\hline$X A$ & Jihomoravská pánev & Vídeňská pánev & Západopanonská pánev & Alpsko-himálajský \\
\hline
\end{tabular}

k tomu, že těmito územními celky byly z výše uvedených důvodů geomorfologické oblasti, bylo nutné získat vektorovou vrstvu s polygony představujícími tyto regiony. Ta byla stažena z Geoportálu Českého úřadu zeměměřického a katastrálního (ČÚZK), kde je součástí databáze Data200 (konkrétně vrstva Popis) [12]. Tato vrstva vychází z geomorfologického členění obsaženého v publikaci [11], jež ve skutečnosti odkazuje na 28 oblastí. V ČHMÚ se však tradičně uvažuje pouze 27 oblastí, nebot Záhorská nížina je sloučena s Jihomoravskou pánví (řádek s ID XA v tab. 2). V tomto smyslu byla také vrstva geomorfologických oblastí před dalšími analýzami upravena.
Digitální model reliéfu (DMR) v podobě rastru, jenž byl zdrojem informací o nadmořské výšce a jiných terénních parametrech v geomorfologických oblastech, vychází z Digitálního modelu území zpracovaného v měřítku 1: 25000 (tzv. DMÚ 25), který ČHMÚ zakoupil v roce 2001 od Vojenského geografického a hydrometeorologického úřadu (VGHMÚřr) generála Josefa Churavého. Tento rastr se čtvercovými buňkami o straně 25 m vznikl z pưvodních dat prímo v ČHMú, přičemž zásadním pro jeho vytvoření byl výškopis ve formě vrstevnic. DMR tak vznikl vhodnou interpolací tehdy ještě v systému S-42. Ale protože ČHMú postupem času přešel na systém UTM zone $33 / 34 N$, byl rastr reprojektován 
a prevzorkován právě do tohoto systému (přesněji pouze pásma 33). Stejně tak byla i geometrie vrstvy polygonů geomorfologických oblastí transformována do systému UTM zone 33N.

Za využití polygonové vrstvy a rastru následovalo extrahování několika charakteristik terénu pro každou geomorfologickou oblast. Ty měly sloužit jako vysvětlující proměnné v plánované regresní analýze. Jejich výčet a význam uvádí tab. 3. Přitom je nutné speciálně upozornit na ukazatel SDASP, který $\checkmark$ české literatuře není príliš znám. Jde o tzv. směrovou směrodatnou odchylku odrážející variabilitu orientace svahů $v$ jednotlivých regionech vyjádřenou v radiánech [13]. Pro výpočet charakteristik terénu souvisejících s úhly byl využit R balíček circular [14]. S vektorovou vrstvou bylo při extrakci manipulováno prostřednictvím R balíčku sf [15], s rastrem naopak pomocí R balíčku terra [16].

\section{Statistické zpracování získaných dat o nadmořské výšce nulové izochiony}

Obr. 4 prozrazuje, kolik hodnot nadmořských výšek nulové izochiony bylo v původní databázi k dispozici od prosince 2012 do května 2021, kdy již pracovníci ČHMÚ vyhodnocovali data kompletně svépomocí. Informace o nadmořské výšce nulové izochiony byla přirozeně k dispozici pouze za zimní období, která obyčejně bývají rozdělena do dvou kalendářních let. Toto rozdělení však není pro další zpracování časových řad príliš vhodné, a proto byly zimní sezony nadále prǐřazovány k rokům s větším podílem měsícủ. Jelikož za zimní sezonu bylo považováno období listopad až květen, měsíce listopady a prosince byly přiřazeny k následujícím kalendářním rokům. Ve výsledku tedy mohly být zimní sezony analyzovány za období 2013-2021, tedy za devět let. Z nejrůznějších důvodů popsaných již dřive nebyla původní databáze pro jednotlivé geomorfologické oblasti kompletní, přičemž dokonce nebyl dodržen ani ekvidistantní týdenní krok, nebot’ např. z důvodu oblačnosti musel být vybrán některý z následujících bezoblačných dnů v týdnu. Chybějící hodnoty a nedodržení stejného časového kroku činí taková data pro následující statistické zpracování poměrně problematickými, protože naprostá většina statistických modelů vyžaduje úplnost a konstantnost časového kroku (zejména jde-li o modely časových řad). Přestože se vyvíjejí také modely pro data tohoto typu (např. [17]), obecně je doporučováno zbavit se jejich výše zmíněných nedostatků, aby mohly být aplikovány tradiční modely. Databáze hodnot nadmořských výšek nulové izochiony byla nakonec doplněna odhady hodnot tak, že pro každou geomorfologickou oblast vznikla časová řada v denním kroku, jež bez jediné chybějící hodnoty reprezentovala všechny zimní sezony období 2013-2021. Tohoto výsledku bylo dosaženo prostřednictvím modifikovaného EM (Expectation-Maximization) algoritmu, který s neúplnou časovou řadou zachází jako s řadou vícerozměrnou, kde je tedy uvažován vektor jednorozměrných řad s vazbami mezi nimi a zároveň je na všechny jeho prvky jako filtr aplikována metoda splinů. Mnohem podrobněji je algoritmus popsán v [18], přičemž stejní autoři jej implementovali do R balíčku mtsdi [19], jehož funkce mnimput byla také využita pro doplnění chybějících denních hodnot.

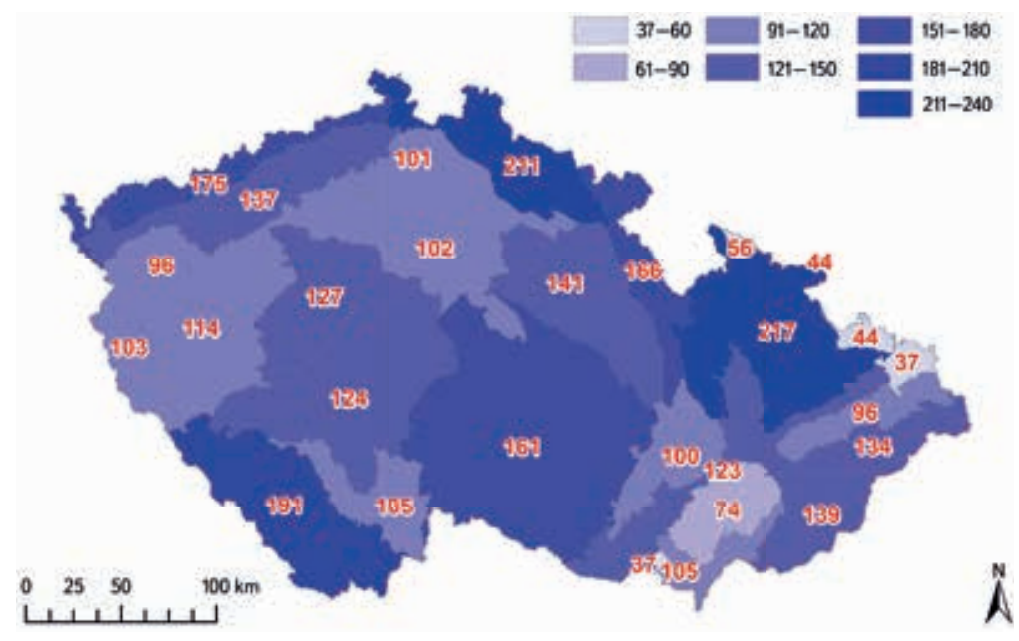

Obr. 4. Celkový počet dní (hodnot) s detekovanou nulovou izochionou za všechna období zim 2013-2021

Fig. 4. Total number of days (values) with the detected zero isochion for all winter seasons 2013-2021

Tab. 3. Charakteristiky geomorfologických oblastí Česka získanéjako potenciální vysvětlujici promènné pro návaznou regresní analýzu

Tab. 3. Characteristics of geomorphological regions of Czechia obtained as explanatory variables for next regression analysis

\section{Proměnná/Variable Význam/Meaning}

\begin{tabular}{ll}
\hline$X$ & souřadnice $X$ centroidu polygonu představujícího geomorfologickou oblast (pro zobrazení UTM zone 33N) \\
\hline$Y$ & souřadnice $Y$ centroidu polygonu představujícího geomorfologickou oblast (pro zobrazení UTM zone 33N) \\
\hline MIN & minimální nadmořská výška geomorfologické oblasti odvozená z DMR \\
\hline MAX & maximální nadmořská výška geomorfologické oblasti odvozená z DMR \\
\hline RANGE & rozpětí mezi maximální a minimální nadmořskou výškou \\
\hline SDEIAN & mediánová nadmořská výška geomorfologické oblasti zjištěná z DMR \\
\hline MEDSLOPE & směrodatná odchylka nadmořských výšek určených pro každou buňku DMR spadající do geomorfologické oblasti \\
\hline MEANASP & $\begin{array}{l}\text { mediánový sklon svahů určený z DMR pro geomorfologickou oblast } \\
\text { zjištěná z DMR orientace svahů v geomorfologické oblasti (kategorie sever = North, východ = East, jih = South a západ = West) }\end{array}$ \\
\hline SDASP & $\begin{array}{l}\text { směrodatná odchylka radiánů určujících orientaci svahů v geomorfologické oblasti zjištěná z DMR (podle [13]) } \\
\text { prevevažující orientace svahů v geomorfologické oblasti (kategorie sever = North, východ = East, jih = South a západ = West) }\end{array}$ \\
\hline
\end{tabular}


Tab. 4. Hodnoty vybraných terénnich vysvětlujicich proměnných pro 27 geomorfologických oblastí Česka

Tab. 4. Values of selected explanatory variables related to terrain of the 27 geomorphological regions of Czechia

\begin{tabular}{|c|c|c|c|c|c|c|c|c|c|c|c|}
\hline $\begin{array}{l}\text { Oblast/ } \\
\text { Region }\end{array}$ & $\begin{array}{l}X \\
{[\mathrm{~m}]}\end{array}$ & $\begin{array}{l}Y \\
{[\mathrm{~m}]}\end{array}$ & $\begin{array}{l}\text { MIN } \\
{[\mathrm{m}]}\end{array}$ & $\begin{array}{l}\text { MAX } \\
{[\mathrm{m}]}\end{array}$ & $\begin{array}{l}\text { RANGE } \\
{[\mathrm{m}]}\end{array}$ & $\begin{array}{l}\text { MEDIAN } \\
{[\mathrm{m}]}\end{array}$ & $\begin{array}{l}\text { SD } \\
{[\mathrm{m}]}\end{array}$ & $\begin{array}{l}\text { MEDSLOPE } \\
{\left[{ }^{\circ}\right]}\end{array}$ & MEANASP & $\begin{array}{l}\text { SDASP } \\
\text { [rad] }\end{array}$ & PREVASP \\
\hline $\mid A$ & 336085,9 & 5501474,3 & 371 & 1039 & 668 & 532 & 96,2 & 4,12 & East & 2 & East \\
\hline IB & 424956,4 & 5423466 & 387 & 1373 & 986 & 704 & 187,5 & 6,32 & North & 2,09 & North \\
\hline$\| \mathrm{A}$ & 453643,9 & 5489265,7 & 190 & 723 & 533 & 453 & 71,8 & 3,82 & East & 2,39 & South \\
\hline$\| B$ & 470010 & 5433611,5 & 361 & 576 & 215 & 436 & 35,6 & 1,15 & East & 1,94 & East \\
\hline IIC & 546326,6 & 5472446,7 & 193 & 836 & 643 & 517 & 99,6 & 3,62 & East & 2,4 & East \\
\hline IID & 622653,7 & 5467326,5 & 186 & 731 & 545 & 386 & 113,4 & 4,87 & East & 2,18 & East \\
\hline IIIA & 367418,7 & 5593028,7 & 112 & 1242 & 1130 & 651 & 183,8 & 6,45 & South & 2,06 & South \\
\hline$\| \mathrm{I}$ & 394800,1 & 5587386,7 & 115 & 929 & 814 & 354 & 136,6 & 3,82 & East & 2,03 & East \\
\hline$\| I I C$ & 347914,8 & 5546078,6 & 373 & 980 & 607 & 642 & 88,7 & 4,73 & East & 2,38 & North \\
\hline IVA & 522349,7 & 5617564,5 & 211 & 1595 & 1384 & 476 & 211 & 7,18 & South & 2,24 & South \\
\hline IVB & 600425,4 & 5562851,7 & 291 & 1111 & 820 & 485 & 131,8 & 5,74 & South & 2,09 & South \\
\hline IVC & 667559,9 & 5532656,7 & 200 & 1491 & 1291 & 510 & 191,4 & 6,45 & East & 2,14 & East \\
\hline IVD & 649892 & 5580222,8 & 220 & 517 & 297 & 307 & 48,6 & 2,06 & North & 1,36 & North \\
\hline IXA & 621997,1 & 5409837,4 & 159 & 543 & 384 & 250 & 55,9 & 5,82 & East & 2,3 & East \\
\hline IXB & 653086,3 & 5440624,5 & 162 & 583 & 421 & 269 & 66,9 & 5,17 & East & 2,74 & East \\
\hline IXC & 703041 & 5442909,3 & 174 & 1014 & 840 & 383 & 141 & 7,75 & West & 2,03 & West \\
\hline IXD & 723701,4 & 5496110,8 & 206 & 954 & 748 & 327 & 72,5 & 3,98 & North & 1,95 & North \\
\hline IXE & 736095,5 & 5484037,7 & 268 & 1318 & 1050 & 575 & 161,9 & 13,3 & West & 2,49 & West \\
\hline VA & 433084,5 & 5535094,7 & 169 & 861 & 692 & 391 & 122,8 & 3,62 & East & 2,08 & North \\
\hline VB & 379855 & 5516508,7 & 231 & 770 & 539 & 435 & 71,1 & 3,43 & East & 2,24 & North \\
\hline VIA & 493822 & 5599526,8 & 146 & 656 & 510 & 305 & 55,9 & 3,46 & South & 2,06 & South \\
\hline VIB & 478917,2 & 5567738,2 & 133 & 455 & 322 & 219 & 47,3 & 1,22 & East & 1,95 & East \\
\hline VIC & 570293,1 & 5545613,1 & 193 & 692 & 499 & 276 & 104 & 1,46 & East & 2,35 & East \\
\hline VIIA & 718084,5 & 5539710,4 & 200 & 316 & 116 & 255 & 22 & 1,81 & East & 1,83 & East \\
\hline VIIIA & 645831,3 & 5461667,5 & 161 & 382 & 221 & 222 & 31,8 & 1,15 & East & 1,76 & East \\
\hline VIIIB & 743139,7 & 5525269,4 & 192 & 331 & 139 & 240 & 28,7 & 1,28 & East & 1,92 & East \\
\hline XA & 651910 & 5415331,2 & 145 & 300 & 155 & 177 & 21,4 & 0,91 & East & 2,04 & East \\
\hline
\end{tabular}

Denní hodnoty byly nadále agregovány pro jednotlivé roky (respektive zimní sezony) pomocí alfa-useknutého průměru, aby se předešlo citlivosti na extrémy (blíže k jeho vlastnostem viz např. [20]). Useknuto bylo 10 \% extrémních hodnot. Pro roky, u nichž to bylo možné, byly navíc hodnoty agregovány tak, aby reprezentovaly kromě kompletního období (značeného jako KOMPLET) také jednotlivé etapy zimních sezon (tj. AKUMULACE, TÁNÍ a nerozlišitelný ZBYTEK mezi akumulací a táním). Pro definici období akumulace, respektive tání, byl jako referenční použit vývoj sněhové pokrývky v pohraničních horách, především pak v Krkonoších a Jizerských horách. Nebylo přitom počítáno s možnými překryvy těchto období způsobenými prípadnými oblevami. Avšak různé trvání jednotlivých období v různých letech bylo zaručeno. Poté došlo taktéž k agregaci přes všechny roky, aby byly získány "dlouhodobé" hodnoty jako vysvětlované proměnné pro připravované regresní modely. Datumy vymezující období akumulace a tání sněhu přirozeně nebyly ve všech letech stejné, a proto se postupovalo striktně podle toho, co bylo pozorováno kombinací družicových snímků a terénního průzkumu. Pro období TÁNí nebylo datum jeho začátku 
Tab. 5. Dlouhodobé průměry nadmořské výšky nulové izochiony za zimní období (listopad-květen) pro 27 geomorfologických oblastí Česka

Tab. 5. Long-term averages of the zero isochion altitude for winter seasons (November-May) for the 27 geomorphological regions of Czechia

\begin{tabular}{|c|c|c|c|c|c|}
\hline Oblast/Region & $\begin{array}{l}\text { KOMPLET/ALL } \\
(2013-2021)[\mathrm{m}]\end{array}$ & $\begin{array}{l}\text { KOMPLET/ALL } \\
(2018-2021)[\mathrm{m}]\end{array}$ & $\begin{array}{l}\text { AKUMULACE/ACCUMULATION } \\
(2018-2021)[\mathrm{m}]\end{array}$ & $\begin{array}{l}\text { TÁNÍ/MELT } \\
(2018-2021)[\mathrm{m}]\end{array}$ & $\begin{array}{l}\text { ZBYTEK/REST } \\
(2018-2021)[\mathrm{m}]\end{array}$ \\
\hline IA & 616 & 625 & 601 & 648 & 667 \\
\hline IB & 808 & 808 & 748 & 914 & 782 \\
\hline$\| \mathrm{A}$ & 450 & 445 & 440 & 454 & 442 \\
\hline$\| \mathrm{B}$ & 439 & 437 & 439 & 436 & 432 \\
\hline$\| \mathrm{C}$ & 539 & 537 & 516 & 572 & 545 \\
\hline IID & 450 & 453 & 445 & 472 & 452 \\
\hline$\| I I A$ & 699 & 697 & 626 & 842 & 705 \\
\hline IIIB & 404 & 396 & 388 & 400 & 422 \\
\hline$\| I C$ & 663 & 682 & 654 & 724 & 685 \\
\hline IVA & 651 & 638 & 568 & 818 & 573 \\
\hline IVB & 612 & 618 & 555 & 750 & 606 \\
\hline IVC & 683 & 678 & 570 & 873 & 699 \\
\hline IVD & 351 & 360 & 359 & 357 & 363 \\
\hline IXA & 212 & 201 & 193 & 204 & 228 \\
\hline IXB & 282 & 280 & 295 & 264 & 265 \\
\hline IXC & 500 & 511 & 448 & 594 & 554 \\
\hline IXD & 391 & 386 & 366 & 414 & 439 \\
\hline IXE & 627 & 625 & 575 & 700 & 622 \\
\hline VA & 493 & 495 & 498 & 503 & 465 \\
\hline VB & 459 & 465 & 464 & 463 & 473 \\
\hline VIA & 322 & 319 & 313 & 328 & 319 \\
\hline VIB & 254 & 247 & 248 & 247 & 248 \\
\hline VIC & 352 & 342 & 330 & 348 & 370 \\
\hline VIIA & 251 & 249 & 248 & 251 & 240 \\
\hline VIIIA & 212 & 209 & 212 & 208 & 203 \\
\hline VIIIB & 241 & 236 & 236 & 235 & 235 \\
\hline$X A$ & 182 & 178 & 178 & 178 & 178 \\
\hline
\end{tabular}

v př́padě několika geomorfologických oblastí k dispozici, a proto bylo nahrazeno posledním datumem období ZBYTEK. Překryvy období uvažovány nebyly, spíše bylo cíleno na delší charakter období.

Z několika důvodů, mezi něž patřilo i množství získaných dat determinované počtem geomorfologických oblastí, byl pro samotnou regresní analýzu nakonec vybrán lineární model (vícerozměrný aditivní s odhadem parametrů pomocí metody obyčejných nejmenších čtverců) a model náhodných lesů. Terénní vysvětlující proměnné byly $v$ prvním případě vybírány na základě Akaikeho informačního kritéria (za kombinace dopředného a zpětného hledání proměnných; bliže viz [21, 22]). Výběr vysvětlujících proměnných konkrétně probíhal prostřednictvím funkce stepAIC implementované v R balíčku MASS, jenž je součástí knihy [23]. Před aplikací lineárních modelů byla speciálně zkoumána možná kolinearita mezi nabízenými vysvětlujícími proměnnými pomocí Pearsonových korelačních koeficientů. V prípadě náhodných lesů byl aplikován dopředný výběr pomocí funkce ffs implementované v R balíčku CAST [24-26], který ke svému fungování potřebuje především $\mathrm{R}$ baličky caret [27, 28] a randomForest [29]. 
Tab. 6. Nejlepši lineární modely podle Akaikeho informačního kritéria

Tab. 6. Best linear models according to the Akaike Information Criterion

\begin{tabular}{|c|c|c|c|c|c|}
\hline & Koeficient/Coefficient & Odhad/Estimate & Střední chyba/Std. error & $t$ & $P(>|t|)$ \\
\hline KOMPLET/ALL (2013-2021) & absolutní člen/intercept & $-73,65$ & 35,43 & $-2,08$ & 0,05 \\
\hline$\left(R^{2}=0,99\right.$ & $x$ & $6 \times 10^{-5}$ & $5 \times 10^{-5}$ & 1,39 & 0,18 \\
\hline$F=297,5$ & MIN & 0,22 & 0,09 & 2,61 & 0,02 \\
\hline \multirow[t]{4}{*}{$p<0,01)$} & MAX & 0,12 & 0,05 & 2,65 & 0,02 \\
\hline & MEDIAN & 0,75 & 0,07 & 10,16 & $<0,01$ \\
\hline & SD & 0,81 & 0,27 & 2,97 & 0,01 \\
\hline & MEDSLOPE & $-9,28$ & 2,83 & $-3,28$ & $<0,01$ \\
\hline $\begin{array}{l}\text { AKUMULACE/ACCUMULATION } \\
(2018-2021)\end{array}$ & absolutní člen/intercept & $-701,23$ & 536,17 & $-1,31$ & 0,21 \\
\hline$\left(R^{2}=0,99\right.$ & Y & $1 \times 10^{-4}$ & $1 \times 10^{-4}$ & 1,3 & 0,21 \\
\hline$F=174,7$ & MIN & 0,35 & 0,1 & 3,52 & $<0,01$ \\
\hline \multirow{3}{*}{$p<0,01)$} & MEDIAN & 0,73 & 0,08 & 9,72 & $<0,01$ \\
\hline & SD & 0,88 & 0,18 & 4,74 & $<0,01$ \\
\hline & MEDSLOPE & $-4,79$ & 3,05 & $-1,57$ & 0,13 \\
\hline TÁNÍ/MELT (2018-2021) & absolutní člen/intercept & $-229,44$ & 95,66 & $-2,4$ & 0,03 \\
\hline$\left(R^{2}=0,99\right.$ & $x$ & $3 \times 10^{-4}$ & $8 \times 10^{-5}$ & 3,41 & $<0,01$ \\
\hline$F=112,5$ & MIN & 0,21 & 0,15 & 1,42 & 0,17 \\
\hline \multirow[t]{8}{*}{$p<0,01)$} & MAX & 0,25 & 0,08 & 3,08 & 0,01 \\
\hline & MEDIAN & 0,94 & 0,12 & 7,76 & $<0,01$ \\
\hline & SD & 0,96 & 0,45 & 2,11 & 0,05 \\
\hline & MEDSLOPE & $-16,43$ & 7,28 & $-2,26$ & 0,04 \\
\hline & MEANASPEast & 53,18 & 28,32 & 1,88 & 0,08 \\
\hline & MEANASPSouth & 90,72 & 30,27 & 3 & 0,01 \\
\hline & MEANASPWest & 65,25 & 45,08 & 1,45 & 0,17 \\
\hline & SDASP & $-63,21$ & 37,96 & $-1,67$ & 0,12 \\
\hline ZBYTEK/REST (2018-2021) & absolutní člen/intercept & $-9,28$ & 29,79 & $-0,31$ & 0,76 \\
\hline$\left(R^{2}=0,97\right.$ & MAX & 0,25 & 0,04 & 6,14 & $<0,01$ \\
\hline$F=115,2$ & MEDIAN & 0,82 & 0,08 & 10,62 & $<0,01$ \\
\hline \multirow[t]{4}{*}{$p<0,01)$} & MEDSLOPE & $-17,03$ & 5,59 & $-3,04$ & 0,01 \\
\hline & MEANASPEast & $-9,63$ & 21,8 & $-0,44$ & 0,66 \\
\hline & MEANASPSouth & $-29,39$ & 26,61 & $-1,1$ & 0,28 \\
\hline & MEANASPWest & 86,3 & 43,79 & 1,97 & 0,06 \\
\hline
\end{tabular}

t-kvantil Studentovat-rozdělení/Studentt-distribution quantile; P-pravdëpodobnost/probability; F-kvantil Fisherova-Snedecorova F-rozdëlení/Fisher-Snedecor F-distribution quantile; $p$ - $p$-hodnota / p-value 


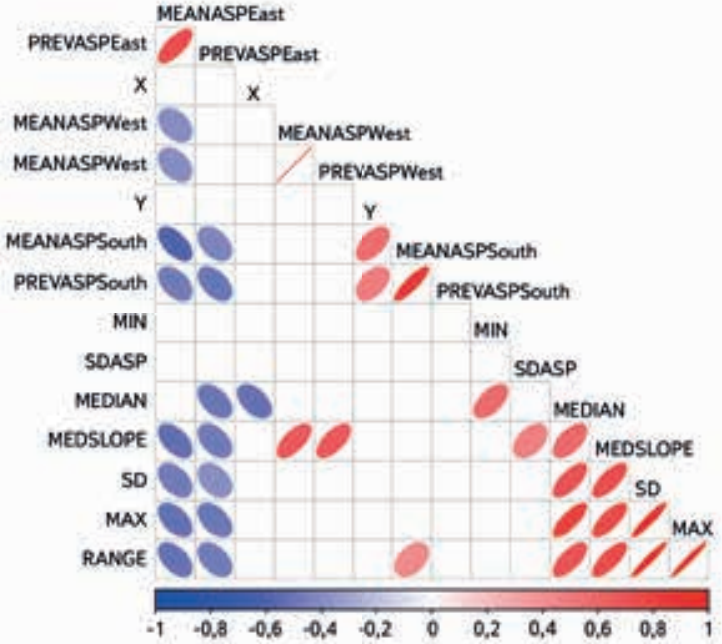

Obr. 5. Pearsonovy korelace mezi vybranými terénními vysvětlujícími proměnnými (elipsami a barvami znázorněny pouze korelace významné na hladině 0,05) Fig. 5. Pearson's correlations between selected explanatory variables related to terrain (by ellipses and colours depicted only correlations significant at the 0.05 level)

Ke zjištění, zda Ize v nadmořské výšce nulové izochiony pozorovat významný meziroční monotónní trend, byl pro jednotlivé geomorfologické oblasti aplikován neparametrický Mannův-Kendallův test. Vzhledem k tomu, že tento test je i přes svůj neparametrický charakter citlivý na autokorelovanost v časové řadě, byla pro řadu období KOMPLET (2013-2021) zvolena modifikace TFPW (trend-free pre-whitening) implementovaná v R balíčku zyp [30]. Teoretické základy této modifikace testu Ize studovat v publikacích [31-33]. Ostatní části zimních období nemohly být takto studovány, protože získané časové řady jsou zatím velmi krátké.

\section{VÝSLEDKY A DISKUZE}

Obr. 4. ukazuje, kolik hodnot nadmořských výšek nulové izochiony se celkem podařilo ze snímků MODIS odvodit pro každou z 27 geomorfologických oblastí používaných v praxi hydrologie ČHMÚ. Celkově bylo tedy za období prosinec 2012 až květen 2021 k dispozici 3216 takových hodnot, což z možného celkového množství denních hodnot (při uvážení všech zimních období obsažených v době od listopadu 2012 do května 2021, tj. 51570 hodnot) činí zhruba 6,24%. Není to způsobeno jen tím, že se hydrologové ČHMÚ tradičně soustředí pouze na získání jedné hodnoty týdně pro každou oblast, ale také tím, že některé oblasti postihuje oblačnost mnohem častěji než jiné. Zároveň je třeba podotknout, že u nížinných oblastí je pravděpodobnost zasněžení mnohem menší než u oblastí vyznačujících se spíše horským reliéfem. Na obr. 4 je tento fakt zdůrazněný metodou nepravého kartogramu, kde jsou geomorfologické oblasti zařazeny do jednotlivých tříd, které se vyznačují různou intenzitou modré barvy. Rozdíl, jenž je zcela jistě způsoben typickou nadmořskou výškou nebo členitostí uvnitř regionů, je velmi dobře patrný. Kromě výše uvedeného je nutné zohlednit i fakt, že vzhledem k plošnému výskytu i době setrvání sněhové pokrývky lze zimy v předešlých pěti letech hodnotit spíše jako podprůměrné, což Ize názorně sledovat na průběžných statistikách [2].

$\checkmark$ tab. 4 jsou výsledky týkající se extrakce vybraných terénních proměnných, u kterých bylo predpokládáno, že mohou vysvětlit prostorovou variabilitu nadmořské výšky nulové izochiony, a mohou být tedy významné pro sestavení regresních modelů. Seznam proměnných, jež lze takto odvodit z DMR, není jistě vyčerpávající, ale předpokládalo se, že reprezentuje alespoň ty nejdůležitější faktory související se zeměpisnou šîřkou, délkou a střední, minimální
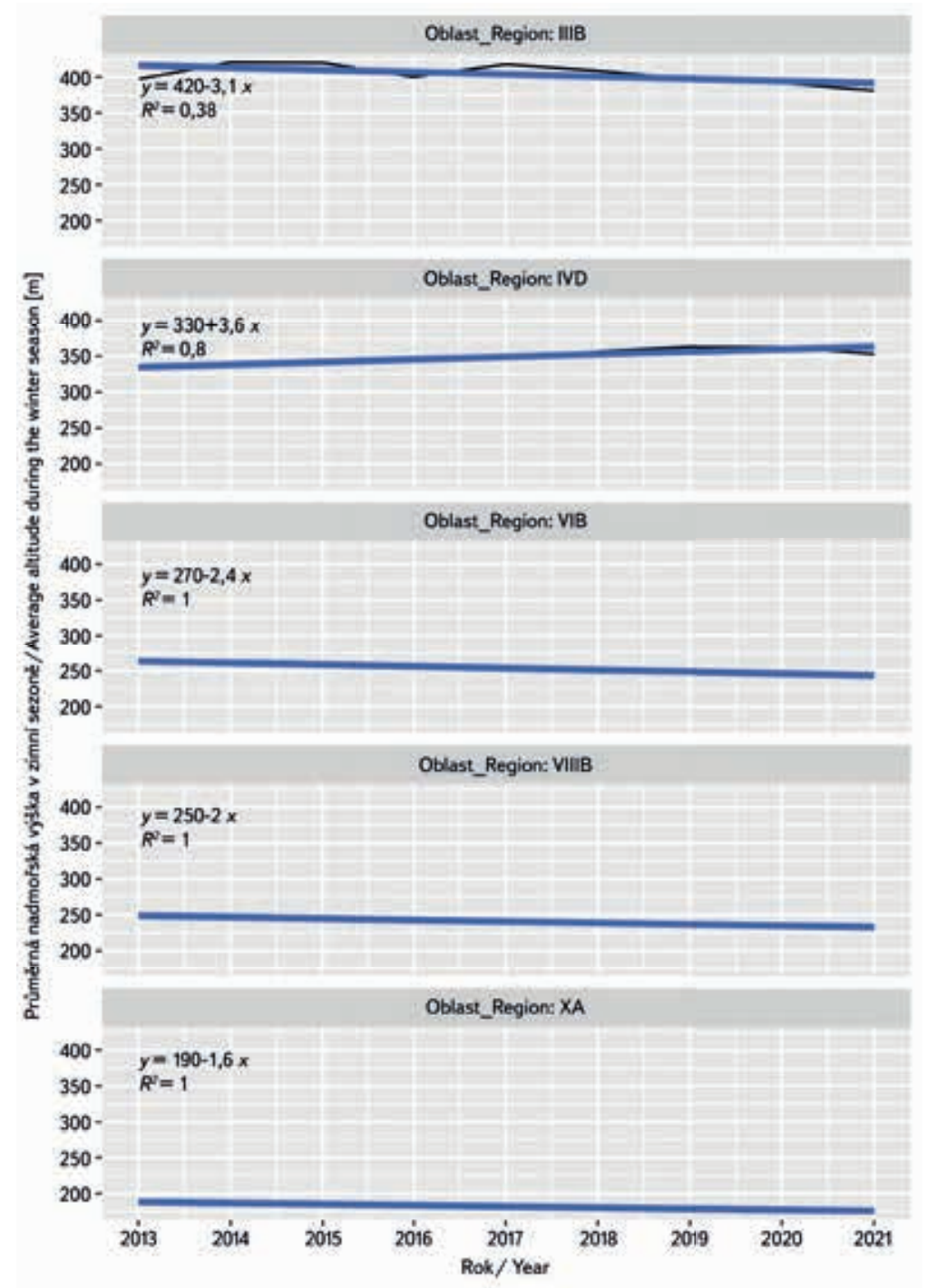

Obr. 6. Průběh ročních řad průměrné nadmořské výšky nulové izochiony (2013-2021) v pěti geomorfologických oblastech Česka, u kterých byl nalezen statisticky významný monotónní trend na hladině 0,01 (černá čára: konkrétní hodnoty výšky; modrá př́mka: lineární trend získaný metodou obyčejných nejmenších čtverců)

Fig. 6. Course of the annual series of average zero isochion altitude (2013-2021) in five geomorphological units in Czechia for which a statistically significant monotonic trend was found at the 0.01 level (black line: specific altitude values; blue line: linear trend obtained by the ordinary least squares method)

i maximální nadmořskou výškou, členitostí a sklonitostí terénu, stejně jako i s orientací svahů. Zvláštní postavení zde zaujímají charakteristiky týkající se variability nadmořské výšky, ale též orientace svahů vůči světovým stranám. Ukazatele spojené s orientací svahů bylo možné vyjádřit v úhlech, ale nakonec bylo rozhodnuto, že do regresních modelů vstoupí jako kategorické proměnné vzniklé reklasifikací, nebot’ v takových modelech není jednoduché počítat s úhlovými veličinami a tak jako tak je doporučována jejich transformace, přičemž jsou zpravidla aplikovány goniometrické funkce.

Tab. 5 poskytuje alespoň základní představu o tom, jaké jsou dlouhodobé (lépe řečeno dlouhodobější) hodnoty nadmořské výšky nulové izochiony na území jednotlivých geomorfologických oblastí Česka. Kromě toho je v tab. 5 ukázáno, jak se tyto dlouhodobé charakteristiky liší podle jednotlivých etap zimní sezony (tj. období akumulace, tání a prostřední období, kdy akumulaci či tání nelze rozlišit), a to alespoň pro roky 2018-2021. Je třeba poznamenat, že 
Tab. 7. Vysvětlujicí proměnnévybrané algoritmem podle [25] pro modely náhodných lesi Tab. 7. Explanatory variables selected by the algorithm of [25] for random forest models

\section{Vysvětlující proměnná/ \\ Explanatory variable}

\begin{tabular}{ll}
\hline KOMPLET/ALL (2013-2021) & MAX \\
\hline$\left(R^{2}=0,93\right.$ & MEDIAN \\
\hline $\operatorname{RMSE}=45,79$ & $X$ \\
\hline
\end{tabular}

RRMSE $=10,18)$

\section{AKUMULACE/ACCUMULATION (2018-2021)}

\section{MEDIAN}

\begin{tabular}{ll}
\hline$\left(R^{2}=0,93\right.$ & SD \\
\hline RMSE $=40,44$ & MIN \\
\hline RRMSE $=9,49)$ & \\
\hline TÁNÍ/MELT (2018-2021) & MAX \\
\hline$\left(R^{2}=0,92\right.$ & MEDIAN \\
\hline RMSE $=61,09$ & SDASP
\end{tabular}

RRMSE $=12,5)$

\begin{tabular}{ll}
\hline ZBYTEK/REST (2018-2021) & MAX \\
\hline$\left(R^{2}=0,92\right.$ & MEDIAN \\
\hline RMSE $=49,4$ & $X$ \\
\hline
\end{tabular}

RRMSE $=10,92)$

RMSE - odmocninová střední čtvercová chyba / root mean squared error RRMSE - relativní odmocninová střední čtvercová chyba / relative root mean squared error

úplná vícerozměrná řada mohla díky extrapolacím obsahovat též hodnoty větší než maximální a menší než minimální nadmořské výšky vyskytující se v geomorfologických oblastech, což v doplněných datech nastalo u 16 oblastí (jinými slovy u 1,3 \% z celkového počtu denních hodnot). To ale při následujícím použití modelů pro zjištování, které terénní charakteristiky mají vliv na variabilitu nadmořské výšky nulové izochiony, překážku nekladlo. Navíc tyto hodnoty by bylo možné považovat za reálné, kdyby např. nejvyšší partie oblastí dosahovaly odhadovaných pozic. Je rovněž předpokládáno, že tyto situace byly redukovány aplikováním alfa-useknutého průměru.

Pred aplikováním lineárních modelů je doporučováno všímat si zejména pravděpodobné kolinearity mezi vysvětlujícími proměnnými, tj. jevu, při němž dvě nebo více proměnných poskytují velmi podobnou informaci. Obr. 5 prostřednictvím Pearsonových korelací ukazuje, že i přes neúplný seznam terénních proměnných velmi pravděpodobně kolinearita v sadě vysvětlujících proměnných př́tomna byla. Zejména si lze povšimnout velmi těsné (a statisticky významné korelace na hladině 0,05$)$ mezi maximem nadmořské výšky a rozpětím mezi minimem a maximem. Dále je možné vypozorovat velmi těsný vztah mezi oběma veličinami vztahujícími se $\mathrm{k}$ orientaci svahů. Z těchto důvodů nebylo v případě lineárních modelů dále počítáno s rozpětím mezi maximem a minimem nadmořské výšky a s převažující orientací svahů. Alternativou (při ponechání všech dostupných vysvětlujících proměnných) mohly být regresní modely, v nichž jako vysvětlující proměnné figurují namísto původních proměnných hlavní komponenty (viz např. [34]). U modelů náhodných lesů byly před výběrem záměrně ponechány všechny získané terénní vysvětlující proměnné. Poznamenejme ještě, že pro modely náhodných lesů bylo ponecháno původní nastavení parametrů jako např. v [35].

Tab. 6 a 7 již prozrazují, které terénní proměnné byly konkrétně vybrány pro lineární modely (za asistence Akaikeho informačního kritéria), respektive pro modely náhodných lesů (za pomoci dopředného algoritmu podle [25]). Je vidět, že lineární modely jsou mnohem komplexnější, pokud jde o inkluzi vysvětlujících proměnných. Některé proměnné dle statistiky $t$ významné nejsou, ale i tak prrispívají k významnosti celých modelů. Ty jsou dle statistiky $F$ významné dokonce na menších hladinách než 0,05. Rovněž tak hodnoty koeficientů determinace $\left(R^{2}\right)$ jasně naznačují, že vysvětlení variability dlouhodobé nadmořské výšky nulové izochiony je zde více než dobré. Za cenu snížení hodnot $R^{2}$ algoritmus u modelů náhodných lesů vybral vysvětlujících proměnných méně. Velmi často zde vystupuje zeměpisná délka a extrémy nadmořské výšky. Stálou vysvětlující proměnnou je tu charakteristika související se střední nadmořskou výškou geomorfologických oblastí, což potvrzuje situaci na obr. 4. Pro období akumulace a tání sněhu se zdají být důležitými také charakteristiky spjaté s variabilitou nadmořské výšky ( $v$ prípadě akumulace) a orientace svahů (v případě tání), což zní poměrně logicky. Je však třeba poznamenat, že náhodný les je model založený na resamplovacích technikách, takže při jiném běhu algoritmu může dojít k nepatrně odlišnému výběru proměnných. Domníváme se ale, že i tak by tyto výběry byly velice podobné. Např. pro tání sněhu bude důležitá variabilita orientace svahu, jež souvisí s príznivými nebo naopak nepříznivými podmínkami v průběhu světlé části dne.

Analýza trendů, a tedy meziroční časové variability nadmořské výšky nulové izochiony byla provedena jen pro nejdelší časovou řadu označenou jako KOMPLET, protože období čtyř let, pro které je k dispozici rozdělení podle jednotlivých fází prírůstku a úbytku sněhové pokrývky, není možné pro tento typ analýzy ještě považovat za reprezentativní. Z tab. 8 je jasné, že během zimních sezon 2013-2021 byla nulová izochiona spíše stabilní. Přesto je však možné si povšimnout, že $v$ pěti regionech pravděpodobně dochází k poklesu (Podkrušnohorská oblast, Středočeská tabule, Severní Vněkarpatské sníženiny, Jihomoravská pánev) či vzestupu nulové izochiony (Krkonošsko-jesenické podhưríi). Důvody pro vznik takových trendů mohou být různé, od skutečných nárůstů či poklesů sněhové pokrývky až po fakt, že data pro některé z těchto regionů nemusela být dostatečná. Tak např. při pohledu na obr. 6, kde jsou černou čarou znázorněny průběhy časových řad jen pro regiony se signifikantním monotónním trendem, je zřejmé, že nejméně tři z těchto výsledků jsou dosti nevěrohodné. K situacím, kdy $R^{2}=1$, nedochází téměř nikdy. Navíc průběhy těchto podežrelých řad nevykazují téměř žádnou variabilitu (např. černé čáry jsou zakryty modrými regresními prímkami), což naznačuje, že spíše selhal EM algoritmus při doplňování chybějících hodnot, který pracoval pouze s několika málo zjištěnými hodnotami, jež mohly být nadto zatíženy velkou nejistotou. Doplňme, že zatímco v obr. 6 jsou regresní prímky konstruovány za využití lineárních modelů, tak v tab. 8 jsou regresní koeficient a absolutní člen pro porovnání výsledků vztaženy k tzv. Senovu neparametrickému odhadu [36].

Pro účely aktualizace tabulky diferencí mezi nadmořskými výškami nulové izochiony $v$ jednotlivých geomorfologických oblastech, kterou uvádí [3], byla sestavena její nová verze (viz tab. 9). Je patrné, že současná čísla se dosti odlišují od těch publikovaných $v$ minulosti. Mohlo např. dojít $k$ určitému zpřesnění, kde aplikovaný alfa-useknutý průměr již k extrémním hodnotám přihlížel jinak. Z praktického hlediska metodiky výpočtu zásob vody ve sněhu je však pro prognostiky ČHMú nejzásadnější vztah mezi horskými pohraničními regiony, kde se sněhová pokrývka vyskytuje nejdéle a nejčastěji. Nutné je ale zmínit i riziko významných jarních povodní z tajícího sněhu, jež je spjato spíše se sněhovou pokrývkou v nižinách, tzn. v tabulích v Polabí. V takových situacích je nulová izochiona bud' zcela potlačena a sníh se vyskytuje na celém území, nebo je hranice poměrně ostrá a ohraničuje nejteplejší oblasti a tepelné ostrovy. Tab. 9 zkušenosti z analýz nulové izochiony jen potvrzuje, predevším pak 
Tab. 8. Výsledky trendové analýzy pro všech 27 geomorfologických oblastí Česka ( $\uparrow$ : statisticky významný rostoucí trend na hladině 0,01; $\downarrow$ : statisticky významný klesající trend na hladinè 0,01 )

Tab. 8. Results of trend analysis for all 27 geomorphological regions of Czechia ( $\uparrow:$ statistically significant increasing trend at the 0.01 level; $\downarrow$ : statistically significant decreasing trend at the 0.01 level)

\begin{tabular}{|c|c|c|c|c|c|}
\hline Oblast/Region & $\begin{array}{l}\text { Kendallovo tau/ } \\
\text { Kendall's tau }\end{array}$ & $\begin{array}{l}p \text {-hodnota/ } \\
p \text {-value }\end{array}$ & $\begin{array}{l}\text { Senova směrnice/ } \\
\text { Sen's slope }\end{array}$ & $\begin{array}{l}\text { Absolutní člen/ } \\
\text { Intercept }\end{array}$ & $\begin{array}{l}\text { Grafické vyjádření trendu/ } \\
\text { Graphical trend expression }\end{array}$ \\
\hline IA & 0,43 & 0,17 & 3,74 & 598,18 & - \\
\hline IB & 0,14 & 0,71 & 4,06 & 782,19 & - \\
\hline$\| \mathrm{A}$ & $-0,36$ & 0,27 & $-1,01$ & 456,15 & - \\
\hline IIB & $-0,36$ & 0,27 & $-0,25$ & 439,8 & - \\
\hline$\| \mathrm{C}$ & $-0,14$ & 0,71 & 0,34 & 534,1 & - \\
\hline IID & 0 & 1 & 1,69 & 447,65 & - \\
\hline$\| \mathrm{A}$ & $-0,14$ & 0,71 & 3,3 & 674,8 & - \\
\hline IIIB & $-0,79$ & $<0,01$ & $-4,19$ & 427,01 & $\downarrow$ \\
\hline IIIC & 0,5 & 0,11 & 7,33 & 624,57 & - \\
\hline IVA & $-0,29$ & 0,39 & 0,23 & 657,84 & - \\
\hline IVB & $-0,07$ & 0,9 & 4,32 & 595,99 & - \\
\hline IVC & 0 & 1 & 0,59 & 670,03 & - \\
\hline IVD & 0,79 & $<0,01$ & 4,29 & 329,09 & $\uparrow$ \\
\hline IXA & $-0,57$ & 0,06 & $-4,39$ & 236,98 & - \\
\hline IXB & $-0,21$ & 0,54 & $-3,3$ & 301,42 & - \\
\hline IXC & 0,14 & 0,71 & 4,65 & 469,41 & - \\
\hline IXD & $-0,5$ & 0,11 & $-1,1$ & 401,11 & - \\
\hline IXE & $-0,07$ & 0,9 & 0,56 & 629,08 & - \\
\hline VA & $-0,14$ & 0,71 & 0,22 & 489,92 & - \\
\hline VB & 0,29 & 0,39 & 1,27 & 451,72 & - \\
\hline VIA & $-0,07$ & 0,9 & 0,12 & 322,8 & - \\
\hline VIB & -1 & $<0,01$ & $-2,44$ & 265,85 & $\downarrow$ \\
\hline VIC & $-0,5$ & 0,11 & $-3,48$ & 368,05 & - \\
\hline VIIA & $-0,43$ & 0,17 & $-0,41$ & 252,38 & - \\
\hline VIIIA & $-0,29$ & 0,39 & $-1,74$ & 219,8 & - \\
\hline VIIIB & -1 & $<0,01$ & $-2,04$ & 251 & $\downarrow$ \\
\hline$X A$ & -1 & $<0,01$ & $-1,6$ & 189,88 & $\downarrow$ \\
\hline
\end{tabular}

nejpoužívanější vztah, a to ten mezi Krkonošskou oblastí a Šumavskou hornatinou. Ten je možné charakterizovat zjednodušeně tím, že sněhová pokrývka na Šumavě začíná vždy o 100 a více výškových metrů výše oproti hranici sněhu v Krkonoších. Důvody pro to Ize spatřovat v členitosti místních regionů, kdy Krkonoše reprezentují spíše strmé svahy a českou část Šumavy naopak pozvolnější prechod do nižších oblastí.
Obr.7 demonstruje príklad výstupu získaného pomocí snímků MODIS a zároveň dokumentuje podmínky úbytku sněhové pokrývky začátkem dubna 2021. Je zde zobrazena nejčastější situace, kdy je sněhová pokrývka prítomna jen v nejvyšších polohách hor, kde je navíc částečně prekryta oblačností. Naopak v nížinách už sníh neleží vůbec, stejně jako se na konci zimy již nevyskytují nejistě definovatelná území se sněhem, jež charakterizuje kód 201 (viz tab. 1). 
Tab. 9. Rozdíly mezi dlouhodobými prưměry nadmořské výšky nulové izochiony za zimni období (listopad-květen) např́č všemi 27 geomorfologickými oblastmi Česka Tab. 9. Differences between long-term averages of the zero isochion altitude for winter seasons (November-May) across all 27 geomorphological regions of Czechia

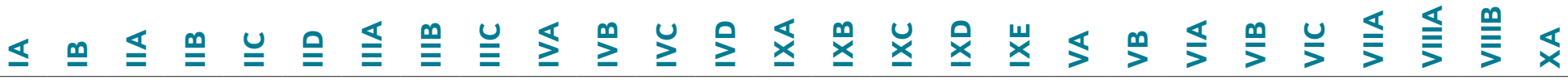

$$
\begin{aligned}
& \leq 0
\end{aligned}
$$

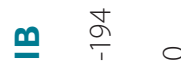

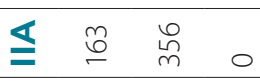

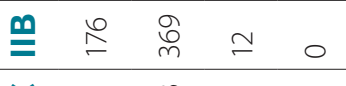

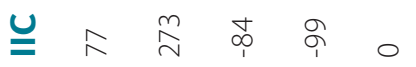

$$
\begin{aligned}
& \text { 으 占望 }
\end{aligned}
$$

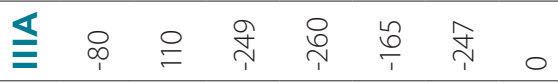

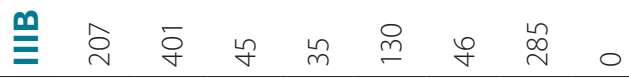

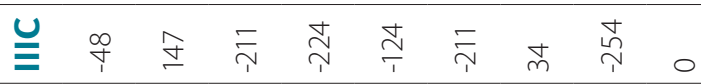

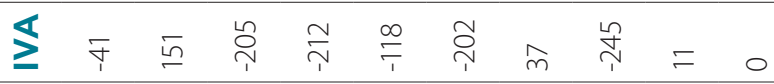

$$
\begin{aligned}
& \text { 药 N } \\
& \text { 药 }
\end{aligned}
$$

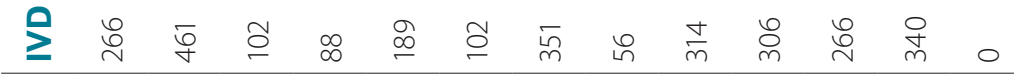

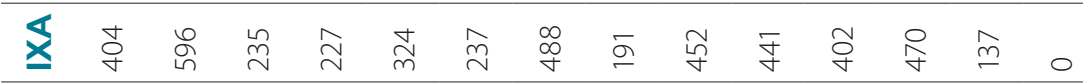

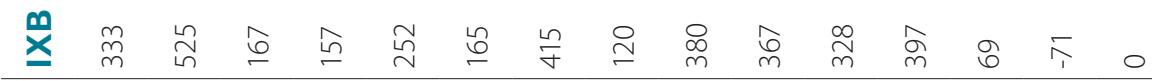$$
\text { 気 }
$$

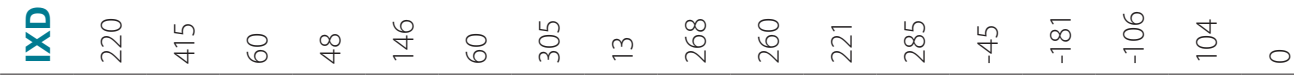

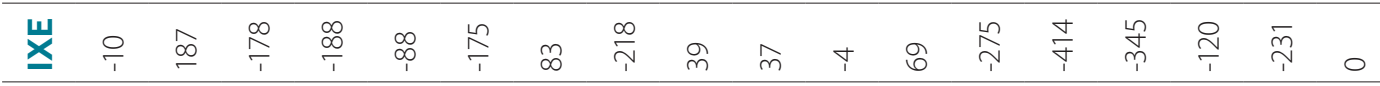

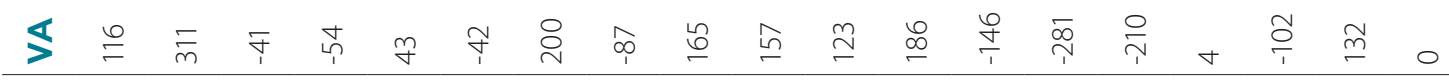

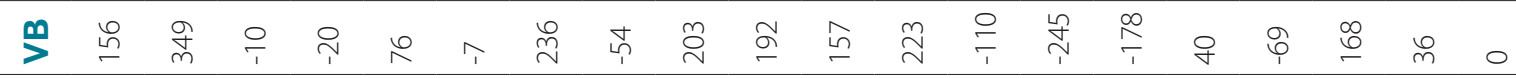

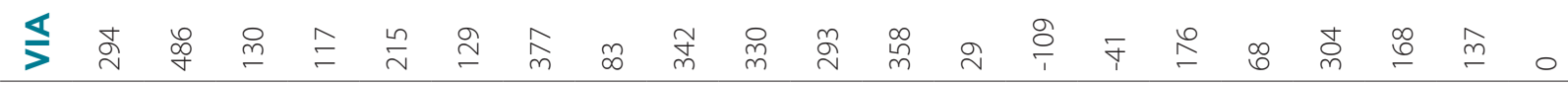

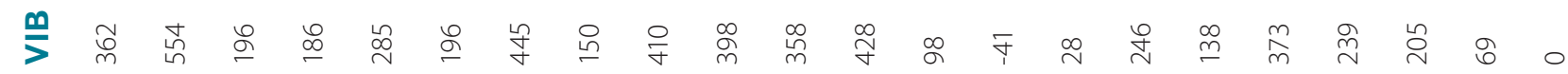

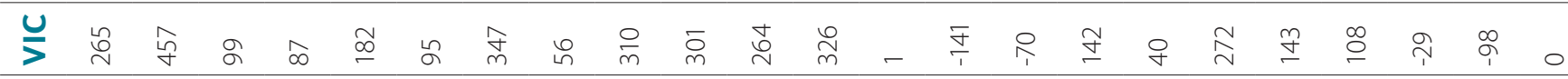

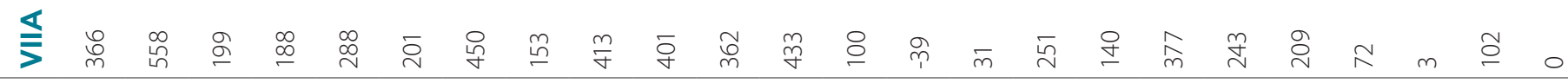

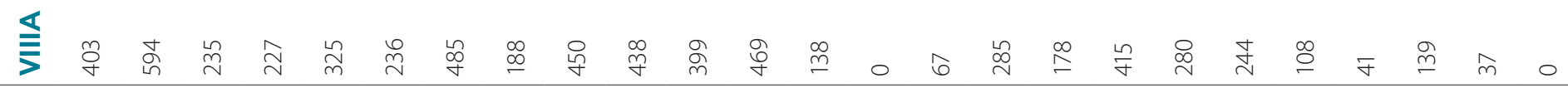

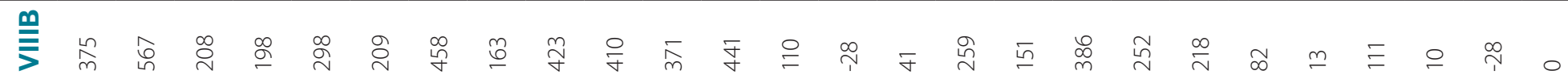

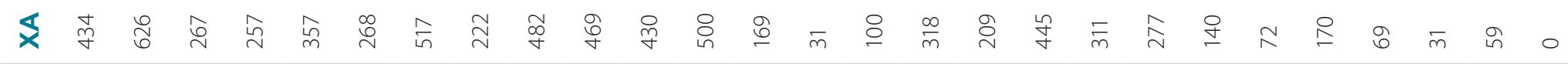




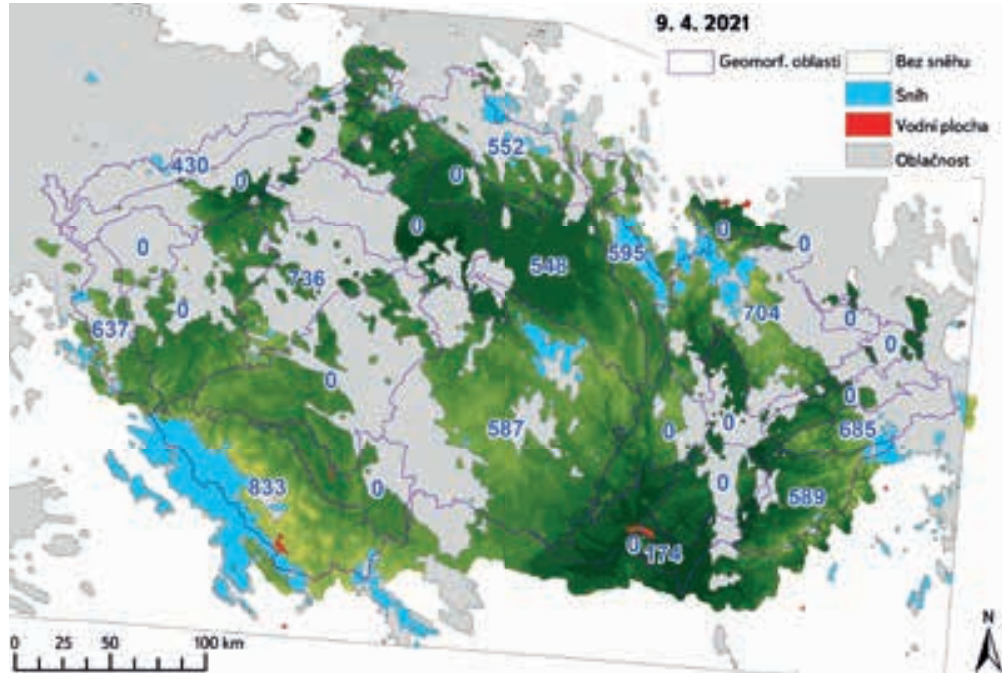

Obr. 7. Analyzovaná situace z 9. dubna 2021, kde jsou vybrané třídy dle tab. 1 zobrazeny nad podkladem DMR (hodnoty určují průměrnou polohu nulové izochiony v m n. m. a 0 znamená oblast bez zaznamenané nulové izochiony)

Fig. 7. Analyzed situation on $9^{\text {th }}$ April 2021 where the selected classes from tab. 1 are depicted above the digital elevation model (values determine the average position of the zero isochion in $\mathrm{m}$ a.s.l. and 0 determines the area without recorded zero isochion)

\section{ZÁVĚR}

V přispěvku jsou uvedeny aktualizované poznatky týkající se nadmořské výšky nulové izochiony, tedy čáry predstavující hranici mezi prostorem se sněhem a prostorem bez sněhu, ve 27 geomorfologických oblastech Česka, které se v praxi hydrologie ČHMÚ využívají pro odhad vodní hodnoty sněhu. Jelikož sníh představuje významnou komponentu tvořící odtok na území Česka, je tato aktivita nezbytná před spouštěním hydrologických modelů použivaných v ČHMÚ jak pro operativní účely, tak i pro bilanční výpočty. Terénní průzkum je finančně i časově nákladný, a navíc neposkytuje dostatečně detailní představu o prostorovém rozložení sněhu v regionech, v Česku často výškově dosti členitých. Proto se pro zpřesnění této představy úspěšně využívají družicové snímky, které po vhodné kalibraci pomocí dat sebraných v terénu mohou být velmi nápomocny i při určení hranice mezi regionem se sněhem a bez sněhu (viz např. [1] a [37]). Studie tak navázala na předchozí výzkum a za využití prodloužené časové řady nadmořských výšek nulové izochiony do května 2021 se snažila odpovědět na otázky nastíněné v závěrech práce [3]. Především byla studována prostorová variabilita nadmořské výšky nulové izochiony a prostřednictvím regresních modelů bylo zjištováno, na kterých faktorech souvisejících s terénem (určených v prostředí GIS z DMR vycházejícího z díla DMÚ 25) závisí kolísání nulové izochiony nejvíce. Za reprezentativní vysvětlovanou proměnnou zde byl brán alfa-useknutý průměr vypočtený z denních hodnot, u něhož bylo prededpokládáno, že redukuje vliv nejistoty v určení polohy nulové izochiony. Průměr nadmořské výšky nulové izochiony v jednotlivých regionech navíc do určité míry představuje limitní polohu, pod kterou již nelze v interpolačních procesech očekávat nenulovou (kladnou) hodnotu výšky sněhové pokrývky a potažmo i vodní hodnoty sněhu. Vzhledem k nejistotám spjatým se snímky MODIS se domníváme, že pokud bude odvozování nulové izochiony vhodně kombinováno s interpolací hodnot získaných pozemním měřením, může část těchto nejistot být do značné míry redukována. Zde sestavené regresní modely vysvětlující prostorovou variabilitu mohou být tedy velmi užitečné např. př́i odhadu (průměrné) pozice nulové izochiony $v$ situacích, kdy jsou regiony z převážné většiny zakryté oblačností. Bylo zjištěno, že velký vliv mají střední, ale i extrémní hodnoty nadmořských výšek. Svưj podíl má zřejmě i zeměpisná délka. V případě akumulace sněhu se k vysvětlujícím proměnným v regresních modelech přidává také směrodatná odchylka vypočítaná z nadmořských výšek vyskytujících se v dané geomorfologické oblasti. V prípadě tání sněhu se zdá být významná směrodatná odchylka získaná ze všech úhlů určujících orientaci svahů. Studium časové variability nadmořské výšky nulové izochiony bylo provedeno trendovou analýzou s cílem zjistit, zda lze vypozorovat př́tomnost monotónních deterministických trendů. Aby byl redukován vliv autokorelace, byla pritom aplikována TFPW modifikace Mannova-Kendallova testu. Z výsledků vyplývá, že $\checkmark$ průběhu zimních sezon se sněhová pokrývka, a tím i nulová izochiona, chovala stabilně. Pouze v pěti geomorfologických jednotkách byl nalezen statisticky významný meziroční trend. Výsledky analýz je ale třeba interpretovat opatrně. Tak např. u tří oblastí vyšel koeficient determinace podezřele roven jedné, což je jev velmi vzácný. Spíše než na skutečnost tento fakt poukazuje na to, že při doplňování chybějících hodnot nadmořské výšky nulové izochiony využitý EM (Expectation-Maximization) algoritmus v některých prípadech selhal. Důvodem byl nedostatek informací, což bylo jistě způsobeno malým množstvím dat získaných ze snímků MODIS, respektive odvozených produktů.

Jak bylo naznačeno výše, na jaře 2022 má dojít k dokončení revizí produktu vycházejícího z indexu NDSI. Tím by mohlo v ČHMÚ následně proběhnout jakési ověření, zda jsou vztahy představené $v$ tomto príspěvku stále platné. Přirozeně se nabízí nasazení (polo)automatického zpracování dat pocházejících ze snímků MODIS za predpokladu, že pracovníci ČHMÚ prohloubí své skriptovací znalosti. Velmi doporučováno je prodloužení časové řady směrem do historie s uvážením, že produkty spojené s detekcí sněhu na zemském povrchu jsou k dispozici již od roku 2000. Nabízí se také „zahuštění" dat s ohledem na skutečnost, že snímky MODIS mají mnohem jemnější časový krok než jeden týden. To může umožnit i aplikaci sofistikovanějších modelů časových řad, než je pouhá analýza trendu. Zpřesní se tak predstava o časové dynamice nulové izochiony, pokud i na straně vysvětlujících proměnných nebudou jen charakteristiky terénu, ale i řady klimatologických prvků. Vysvětlení rozdílů v poloze nulové izochiony Ize totiž hledat též v rozdílu klimatických podmínek, především ve výskytu srážkových situací, jež ovlivñují převážně jihozápad území Česka, přičemž směrem k severním pohořím již nedosahují takových intenzit. Za úvahu rovněž stojí podívat se na další charakteristiky související s nulovou izochionou, které mohou do modelů vstupovat jako vysvětlované proměnné. Zajímavou informaci může hydrologům poskytnout např. gradient změny nulové izochiony nebo změna délky setrvání nulové izochiony nad určitou výškovou hranicí. Podobné ukazatele byly studovány již v [38] a zejména na období tání sněhu a jeho vliv na odtok byla zaměřena studie [39]. Za zmínku stojí rovněž metoda, již je v těchto publikacích nulová izochiona extrahována. Tato metoda se totiž liší od metodiky prezentované zde, a proto se tu přirozeně nabízí srovnání obou prístupů za využití dat pro území Česka.

Zásadním limitem pro přesnější definici polohy nulové izochiony zůstává prostorové rozlišení analyzovaného gridu (500 m). Pro hlubší implementaci nulové izochiony do výpočtu zásob vody ve sněhu je tedy vedle automatizace procesů nutné i prostorové zpresnění. Jednou z možností by mohla být diferenciace reklasifikace produktů s hodnotami indexu NDSI podle různých faktorů, která se dle príspěvku [40] osvědčila na území Rakouska. Podmínkou však je, že délka odvození nulové izochiony bude vyhovovat požadavku operativní hydrologie ČHMÚ mít tento výsledek do 24 hodin. Aktuálně existuji i presnější prostorová data, ovšem opět se značným časovým prodlením mezi jejich pořízením a dostupností. Jistý príslib v horizontu této dekády lze spatřovat v lokálních pozorovacích systémech či v evropském programu Copernicus s misemi Sentinel (viz např. [41]). Neméně důležitým úkolem bude zajisté studium vlastností sněhové pokrývky separátně pro fáze akumulace, tání a ve zbytku zimní sezony, protože - jak výsledky této studie ukázaly - toto dělení má smysl.

$\checkmark$ neposlední řadě se naskýtá otázka, zda není prostřednictvím snímků MODIS výhodnější mapovat plochu sněhové pokrývky přímo. To by bylo možné pouze při ideálních podmínkách za bezoblačnosti, kdy je zaručen 
přehled o celém území Česka, nebo alespoň o všech oblastech se sněhovou pokrývkou. Takových situací je ve skutečnosti pouze minimum, rádově jednotky dní během sezony. Z tohoto důvodu nemůže být aktuálně snímkování MODIS implementováno do výpočtů plochy se sněhovou pokrývkou jako pravidelně používaný nástroj, ale jen jako doplněk k informacím získaným z poměrně husté sněhoměrné sítě ČHMÚ. Naopak jistý potenciál lze najít právě v kalibraci modelu vycházejícího z dostupných řad nadmořské výšky nulové izochiony a jeho schopnosti predikovat pro „neviditelná" místa.

\section{Poděkování}

Oba autori jsou podpořeni v rámci tzv. Dlouhodobékoncepce rozvoje výzkumné organizace (DKRVO) ČHMÚ. Práce O. Ledvinky statistického charakteru je navíc účelově podporena Technologickou agenturou České republiky (projekt SS01020366 "Využití dat dálkového průzkumu Země pro posouzeni negativních dopadů prívalových srážek"). Autorì za tuto podporu vyslovují své diky.

\section{Literatura}

[1] BERCHA, Š. Vyhodnocování zásob vody ve sněhové pokrývce v ČHMÚ. In: KIMLOVÁ, M., ŘlČICOVÁ, P. BERCHA, Š. (eds.). XXI. stretnutie snehárov: sborník přispěvků ze semináre: Žítková 1.-3. 3. 2016 + vybrané nevydané príspěvky z předchozích setkáni [on-line]. Praha: Český hydrometeorologický ústav, 2017, s. 55-56. ISBN 978-80-87577-75-2. Dostupné z: http://www.uh.sav.sk/en-gb/Research/Conferences/Snow-Meetings

[2] ČHMÚ. Hlásná a předpovědní povodňová služba. Informace o velikosti sněhových zásob na územ České republiky [on-line]. 4. květen 2021 [vid. 23. listopad 2021]. Dostupné z: https://www.chmi.cz/files/ portal/docs/poboc/CB/snih/aktual.htm

[3] DUCHÁČEK, L. Vertikální variabilita nulové izochiony v rámci geomorfologických oblastí Česka. Geografie [on-line]. 2014, 119(2), s. 145-160. ISSN 1212-0014, 2571-421X. Dostupné z: doi: 10.37040/ geografie2014119020145

[4] Česká meteorologická společnost. Meteorologický slovník. Elektronický meteorologický slovník [on-line]. 2017 [vid. 25. listopad 2021]. Dostupné z: http://slovnik.cmes.cz/

[5] NASA NSIDC. About Us | National Snow and Ice Data Center [on-line]. 2021 [vid. 23. listopad 2021]. Dostupné z: https://nsidc.org/about/overview

[6] HALL, D. K., RIGGS, G. A. MODIS/Terra Snow Cover 5-Min L2 Swath 500m, Version 61 [on-line]. B.m. NASA National Snow and Ice Data Center DAAC. 2021 [vid. 23. listopad 2021]. Dostupné z: doi: 10.5067/ MODIS/MOD10_L2.061

77] Moderate Resolution Imaging Spectroradiometer [on-line]. 2021 [vid. 26. listopad 2021]. Dostupnéz: https:// en.wikipedia.org/w/index.php?title=Moderate_Resolution_Imaging_Spectroradiometer\&oldid=1048616305

[8] NASA. Terra Spacecraft | NASA [on-line]. 4. srpen 2017 [vid. 23. listopad 2021]. Dostupné z: https:// www.nasa.gov/mission_pages/terra/spacecraft/index.html

[9] Hierarchical Data Format [on-line]. 2021 [vid. 26. listopad 2021]. Dostupné z: https://en.wikipedia org/w/index.php?title=Hierarchical_Data_Format\&oldid=1049571370

[10] NASA. HEG: HDF-EOS to GeoTIFF Conversion Tool - Data Access Services - Earthdata Wiki [on-line] 22. duben 2019 [vid. 23. listopad 2021]. Dostupné z: https://wiki.earthdata.nasa.gov/display/DAS/ HEG\%3A++HDF-EOS+to+GeoTIFF+Conversion+Too

[11] BOHÁČ, P., KOLÁŘ, J. Vyššígeomorfologickéjednotky Českérepubliky. Praha: Český úrad zeměměřický a katastrální, 1996. Geografické názvoslovné seznamy OSN - ČR, A1. ISBN 978-80-901212-7-0.

[12] ČÚZK. ČÚZK: Geoportál. Data200 [on-line].20. leden 2020 [vid.23. listopad 2021]. Dostupnéz: https:// geoportal.cuzk.cz/(S(eew4l3agpixe2uphizmomaed))/Default.aspx?mode=TextMeta\&side=mapy_ data200\&text=dSady_mapyData200\&head_tab=sekce-02-gp\&menu=229

[13] MARDIA, K. V. Statistics of Directional Data. London, New York: Academic Press, 1972. Probability and Mathematical Statistics. ISBN 978-0-12-471150-1.

[14] AGOSTINELLI, C., LUND, U. R Package "Circular": Circular Statistics [on-line]. 2017. Dostupné z: https:// r-forge.r-project.org/projects/circular/

[15] PEBESMA, E. Simple Features for R: Standardized Support for Spatial Vector Data. The R Journal [on-line]. 2018, 10(1), s. 439-446. ISSN 2073-4859. Dostupné z: doi: 10.32614/RJ-2018-009

[16] HIJMANS, R. J. Terra: Spatial Data Analysis [on-line]. 2021. Dostupné z: https://CRAN.R-project.org/ package $=$ terra

[17] VIO, R., WAMSTEKER, W. Tests of Irregularly Sampled Stochastic Time Series for AGN. In: MAOZ, D.. STERNBERG, A., LEIBOWITZ, E. M. (eds.). Astronomical Time Series: Proceedings of The Florence and George Wise Observatory 25 th Anniversary Symposium held in Tel-Aviv, Israel, 30 December 1996-1 January 1997 [on-line]. Dordrecht: Springer Netherlands, 1997, s. 167-170 [vid. 8. červen 2019]. Astrophysics and Space Science Library, 218. ISBN 978-90-481-4895-0. Dostupné z: http://link.springer. com/10.1007/978-94-015-8941-3
[18] JUNGER, W. L., PONCE DE LEON, A. Imputation of Missing Data in Time Series for Air Pollutants. Atmospheric Environment [on-line]. 2015, 102, s. 96-104. ISSN 1352-2310. Dostupné z: doi: 10.1016/j. atmosenv.2014.11.049

[19] JUNGER, W., PONCE DE LEON, A. Mtsdi: Multivariate Time Series Data Imputation [on-line]. 2018. Dostupné z: https://CRAN.R-project.org/package=mtsdi

[20] ZVÁRA, K. Základy statistiky v prostředí R. Praha: Karolinum, 2013. Biomedicínská statistika, IV. ISBN 978-80-246-2447-1.

[21] AKAIKE, H. A New Look at the Statistical Model Identification. IEEE Transactions on Automatic Control [on-line]. 1974, 19(6), s. 716-723. ISSN 0018-9286. Dostupné z: doi: 10.1109/TAC.1974.1100705

[22] KUTNER, M. H., NACHTSHEIM, Ch. J., NETER, J., LI, W. Applied Linear Statistical Models. $5^{\text {th }}$ ed. Boston: McGraw-Hill/Irwin, 2005. Operations and Decision Sciences. ISBN 0-07-238688-6.

[23] VENABLES, W. N., RIPLEY, B. D. Modern Applied Statistics with S. $4^{\text {th }}$ ed. New York: Springer, 2002. Statistics and Computing. ISBN 978-0-387-95457-8.

[24] MEYER, H. CAST: "Caret"Applications for Spatial-Temporal Models [on-line]. 2021. Dostupné z: https:// CRAN.R-project.org $/$ package $=$ CAST

[25] MEYER, H., REUDENBACH, Ch., HENGL, T., KATURJI, M., NAUSS, T. Improving Performance of Spatio-Temporal Machine Learning Models Using Forward Feature Selection and Target-Oriented Validation. Environmental Modelling \& Software [on-line]. 2018, 101, s. 1-9. ISSN 1364-8152. Dostupné z: doi: 10.1016/j.envsoft.2017.12.001

[26] MEYER, H., REUDENBACH, Ch., WÖLLAUER, S., NAUSS, T. Importance of Spatial Predictor Variable Selection in Machine Learning Applications - Moving from Data Reproduction to Spatial Prediction. Ecological Modelling [on-line]. 2019, 411, 108815. ISSN 0304-3800. Dostupné z: doi: 10.1016/j. ecolmodel.2019.108815

[27] KUHN, M. Caret: Classification and Regression Training. [on-line]. 2021. Dostupné z: https://CRAN.Rproject.org/package $=$ caret

[28] KUHN, M., JOHNSON, K. Applied Predictive Modeling [on-line]. New York, NY: Springer New York, 2013 [vid. 15. zárí 2020]. ISBN 978-1-4614-6848-6. Dostupné z: http://link.springer. com/10.1007/978-1-4614-6849-3

[29] LIAW, A., WIENER, M. Classification and Regression by RandomForest. R News. 2002, 2(3), s. 18-22. ISSN 1609-3631.

[30] BRONAUGH, D., WERNER, A. Zyp: Zhang + Yue-Pilon Trends Package [online]. B.m.: Pacific Climate Impacts Consortium, 2019. Dostupné z: https://CRAN.R-project.org/package=zyp

[31] KENDALL, M. G. A New Measure of Rank Correlation. Biometrika [on-line]. 1938, 30(1), s. 81-93. ISSN 0006-3444. Dostupné z: doi: 10.2307/2332226

[32] MANN, H. B. Nonparametric Tests against Trend. Econometrica [on-line]. 1945, 13(3), s. 245-259. ISSN 0012-9682. Dostupné z: doi: 10.2307/1907187

[33] KENDALL, M. G., GIBBONS, J. D. Rank Correlation Methods. $5^{\text {th }}$ ed. New York: Oxford University Press, 1990. ISBN 978-0-19-520837-5.

[34] WILKS, D. S. Statistical Methods in the Atmospheric Sciences [on-line]. $4^{\text {th }}$ ed. Amsterdam: Elsevier, 2019 [vid. 1. ŕíjen 2019]. ISBN 978-0-12-815823-4. Dostupné z: https://linkinghub.elsevier.com/retrieve/ $\mathrm{pii} / \mathrm{C} 20170039216$

[35] MAŤAŠOVSKÁ, V., KOTHAN, F., LEDVINKA, O., PUMANN, P., FOJTÍK, T., MAKOVCOVÁ, M., BENDAKOVSKÁ, L. Využití metod dálkového průzkumu Země pro monitoring stavu koupacích míst. Vodohospodárské technicko-ekonomické informace [on-line]. 2021, 63(1), s. 37-45. ISSN 0322-8916. Dostupné z: doi: 10.46555/VTEI.2020.12.003

[36] SEN, P. K. Estimates of the Regression Coefficient Based on Kendall's Tau. Journal of the American Statistical Association [on-line]. 1968, 63(324), s. 1379-1389. ISSN 0162-1459. Dostupné z: doi: 10.2307/2285891

[37] DENG, G., TANG, Z., HU, G., WANG, J., SANG, G., LI, J. Spatiotemporal Dynamics of Snowline Altitude and their Responses to Climate Change in the Tienshan Mountains, Central Asia, during 2001-2019. Sustainability [on-line]. 2021, 13(7), 3992. ISSN 2071-1050. Dostupné z: doi: 10.3390/su13073992

[38] KRAJČ́, P., HOLKO, L., PARAJKA, J. Variability of Snow Line Elevation, Snow Cover Area and Depletion in the Main Slovak Basins in Winters 2001-2014. Journal of Hydrology and Hydromechanics [on-line]. 2016, 64(1), s. 12-22. ISSN 0042-790X. Dostupné z: doi: 10.1515/johh-2016-0011

[39] PARAJKA, J., BEZAK, N., BURKHART, J., HAUKSSON, B., HOLKO, L., HUNDECHA, Y., JENICEK, M., KRAJČI, P. MANGINI, W. MOLNAR, P. RIBOUST, P., RIZZI, J. SENSOY, A. THIREL, G. VIGLIONE, A. MODIS Snowline Elevation Changes during Snowmelt Runoff Events in Europe. Journal of Hydrology and Hydromechanics [on-line]. 2019, 67(1), s. 101-109. ISSN 0042-790X. Dostupné z: doi: 10.2478/johh-2018-0011 [40] TONG, R., PARAJKA, J., KOMMA, J., BLÖSCHL, G. Mapping Snow Cover from Daily Collection 6 MODIS Products over Austria. Journal of Hydrology [on-line]. 2020, 590, 125548. ISSN 0022-1694. Dostupné z: doi: 10.1016/j.jhydrol.2020.125548

[41] Koordinační rada ministra dopravy pro kosmické aktivity. Informační stránky Koordinační rady ministra dopravy pro kosmické aktivity. Mapová aplikace | CollGS [on-line]. 2021 [vid. 26. listopad 2021]. Dostupné z: https://collgs.czechspaceportal.cz/mapova-aplikace/ 


\section{Autoři}

Mgr. Libor Ducháček ${ }^{1}$

凶libor.duchacek@chmi.cz

ORCID: 0000-0001-6646-3399

\section{Mgr. Ondřej Ledvinka, Ph.D. ${ }^{2}$ \\ 凶ondrej.ledvinka@chmi.cz \\ ORCID: 0000-0002-0203-7064}

'Český hydrometeorologický ústav, oddělení aplikované hydrologie, Jablonec nad Nisou

${ }^{2}$ Český hydrometeorologický ústav, oddělení hydrofondu a bilancí, Praha

Příspěvek prošel lektorským řízením.

DOI: $10.46555 /$ VTEI.2021.11.004

\section{ZERO ISOCHION IN THE FRAMEWORK OF GEOMORPHOLOGICAL REGIONS IN CZECHIA: ITS EXTRACTION FROM THE MODIS IMAGERY AND ITS DYNAMICS \\ DUCHACEK, L.'; LEDVINKA, $0 .^{2}$}

'Czech Hydrometeorological Institute, Applied Hydrology Department, Jablonec nad Nisou

${ }^{2}$ Czech Hydrometeorological Institute, Hydrology Database and Water Budget Department, Prague

Keywords: remote sensing - geographical information systems (GIS) snow cover - snow water storage - CHMI hydrology geomorphology of Czechia

Since December 2012, during every winter season, the altitude of the zero isochion (snowline) has been determined at the Czech Hydrometeorological Institute for the purposes of operational hydrology. The reason is the estimation of the amount of water stored in snow cover, which is inevitable activity for Czech hydrologists who naturally want their forecasting models to give relevant results. In order to get better idea about current spatial distribution of snow cover in Czechia, the information on the zero isochion has been extracted from the MODIS imagery coming from the Terra satellite. The obtained time series represents a relatively long period (currently until May 2021), which offers the possibility of analyzing the spatial and temporal dynamics of the zero isochion in Czechia. In this study, the information about the isochion was divided into 27 geomorphological regions, while the winter season also into the accumulation period and the melting period. The focus was on possible differences between individual regions and time periods, as well as on relationships between zero isochion dynamics and selected factors derived from other geographical data, such as digital elevation model. Due to different reasons, the data on the isochion were incomplete and did not satisfy the requirements for fitting the models which need regularly/evenly spaced sampling. Therefore, missing daily values were estimated so that the series finally covered the winter seasons from November to May. This was accomplished by the application of a suitable modified EM algorithm that respected both the temporal and the spatial structure of the multivariate time series. Correlation and regression analyses followed, where the main aim was to find out if the belonging to a geomorphological region (with its selected attributes) has an influence, and if there are significant interannual changes. 